\title{
Linseed oil and DGAT1 K232A polymorphism: Effects on methane emission, energy and nitrogen metabolism, lactation performance, ruminal fermentation, and rumen microbial composition of Holstein-Friesian cows
}

\author{
S. van Gastelen, ${ }^{*}{ }^{1}$ M. H. P. W. Visker, ${ }^{*} \ddagger$ J. E. Edwards, ${ }^{\star} \S$ E. C. Antunes-Fernandes, ${ }^{*} \#^{2}$ K. A. Hettinga, $\#$ \\ S. J. J. Alferink, † W. H. Hendriks, † H. Bovenhuis, $\ddagger$ H. Smidt, $\S$ and J. Dijkstra† \\ ${ }^{*}$ Top Institute Food and Nutrition, PO Box 557, 6700 AN Wageningen, the Netherlands \\ †Animal Nutrition Group, Wageningen University \& Research, P.O. Box 338, 6700 AH Wageningen, the Netherlands \\ $\ddagger$ Animal Breeding and Genomics Centre, Wageningen University \& Research, PO Box 338, 6700 AH Wageningen, the Netherlands \\ $\S$ Laboratory of Microbiology, Wageningen University \& Research, PO Box 8033, 6700 EJ Wageningen, the Netherlands \\ \#Food Quality and Design Group, Wageningen University \& Research, PO Box 17, 6700 AH Wageningen, the Netherlands
}

\section{ABSTRACT}

Complex interactions between rumen microbiota, cow genetics, and diet composition may exist. Therefore, the effect of linseed oil, DGAT1 K232A polymorphism (DGAT1), and the interaction between linseed oil and DGAT1 on $\mathrm{CH}_{4}$ and $\mathrm{H}_{2}$ emission, energy and $\mathrm{N}$ metabolism, lactation performance, ruminal fermentation, and rumen bacterial and archaeal composition was investigated. Twenty-four lactating Holstein-Friesian cows (i.e., 12 with DGAT1 KK genotype and 12 with DGAT1 AA genotype) were fed 2 diets in a crossover design: a control diet and a linseed oil diet (LSO) with a difference of $22 \mathrm{~g} / \mathrm{kg}$ of dry matter (DM) in fat content between the 2 diets. Both diets consisted of $40 \%$ corn silage, $30 \%$ grass silage, and $30 \%$ concentrates (DM basis). Apparent digestibility, lactation performance, $\mathrm{N}$ and energy balance, and $\mathrm{CH}_{4}$ emission were measured in climate respiration chambers, and rumen fluid samples were collected using the oral stomach tube technique. No linseed oil by DGAT1 interactions were observed for digestibility, milk production and composition, energy and $\mathrm{N}$ balance, $\mathrm{CH}_{4}$ and $\mathrm{H}_{2}$ emissions, and rumen volatile fatty acid concentrations. The DGAT1 KK genotype was associated with a lower proportion of polyunsaturated fatty acids in milk fat, and with a higher milk fat and protein content, and proportion of saturated fatty acids in milk fat compared with the DGAT1 AA genotype, whereas the fat- and protein-corrected milk yield was unaffected by $D G A T 1$. Also, DGAT1 did not affect nutrient digestibility, $\mathrm{CH}_{4}$ or $\mathrm{H}_{2}$ emission, ruminal fermentation or ruminal archaeal and bacterial concentrations. Rumen

Received November 28, 2016

Accepted August 2, 2017.

${ }^{1}$ Corresponding author: sanne.vangastelen@wur.nl

${ }^{2}$ Current address: KeyToxicology, Yalelaan 104, 3584 CM Utrecht, the Netherlands. bacterial and archaeal composition was also unaffected in terms of the whole community, whereas at the genus level the relative abundances of some bacterial genera were found to be affected by DGAT1. The DGAT1 KK genotype was associated with a lower metabolizability (i.e., ratio of metabolizable to gross energy intake), and with a tendency for a lower milk $\mathrm{N}$ efficiency compared with the DGAT1 AA genotype. The LSO diet tended to decrease $\mathrm{CH}_{4}$ production (g/d) by $8 \%$, and significantly decreased $\mathrm{CH}_{4}$ yield (g/kg of DM intake) by $6 \%$ and $\mathrm{CH}_{4}$ intensity ( $\mathrm{g} / \mathrm{kg}$ of fat- and protein-corrected milk) by $11 \%$, but did not affect $\mathrm{H}_{2}$ emission. The LSO diet also decreased ruminal acetate molar proportion, the acetate to propionate ratio, and the archaea to bacteria ratio, whereas ruminal propionate molar proportion and milk $\mathrm{N}$ efficiency increased. Ruminal bacterial and archaeal composition tended to be affected by diet in terms of the whole community, with several bacterial genera found to be significantly affected by diet. These results indicate that DGAT1 does not affect enteric $\mathrm{CH}_{4}$ emission and production pathways, but that it does affect traits other than lactation characteristics, including metabolizability, $\mathrm{N}$ efficiency, and the relative abundance of Bifidobacterium. Additionally, linseed oil reduces $\mathrm{CH}_{4}$ emission independent of DGAT1 and affects the rumen microbiota and its fermentative activity.

Key words: dairy cow, enteric methane production, linseed oil, DGAT1 K232A polymorphism

\section{INTRODUCTION}

Several dietary strategies have been proposed to mitigate enteric $\mathrm{CH}_{4}$ production, including the use of feed additives and improving forage quality (Beauchemin et al., 2009; Martin et al., 2010). Numerous studies have shown the potential of dietary lipid supplementation to reduce $\mathrm{CH}_{4}$ emission, many of which have been 
reviewed by Grainger and Beauchemin (2011) and Hristov et al. (2013). To date, linseed is considered to be one of the most effective dietary lipid sources to reduce enteric $\mathrm{CH}_{4}$ production from dairy cows (Beauchemin et al., 2009; Martin et al., 2010). Relatively few studies have considered the wider consequences of dietary linseed oil on the functioning of the rumen microbial ecosystem. Veneman et al. (2015) reported no effect of linseed oil supplementation on $\mathrm{CH}_{4}$ emission or the rumen microbiota as a whole. Martin et al. (2016) reported significant decreases in $\mathrm{CH}_{4}$ emissions upon extruded linseed supplementation for both corn-silagebased and hay-based diets, whereas the abundance of rumen methanogens was not affected by linseed supply in the corn-silage-based or hay-based diets.

Little is known whether host genetics can also influence the responses to dietary linseed oil. The acyl CoA:diacylglycerol acyltransferase 1 gene, located on chromosome 14, mediates the final step in triglyceride synthesis (Schennink et al., 2008). Many studies have investigated associations between the K232A polymorphism of this gene (i.e., a lysine to alanine substitution on the 232nd amino acid; DGAT1) and milk production traits of dairy cows. Although DGAT1 has no effect on fat- and protein-corrected milk (FPCM) yield, the $D G A T 1 \mathrm{~K}$ allele is associated with a higher fat content, protein content, and fat yield, but lower milk production and protein and lactose yield (e.g., Banos et al., 2008; Näslund et al., 2008; Bovenhuis et al., 2015). Additionally, DGAT1 has a marked effect on milk fatty acid (MFA) composition. The DGAT1 $\mathrm{K}$ allele is associated with a larger fraction of $\mathrm{C} 16: 0$, and smaller fractions of C18 UFA in milk fat (e.g., Schennink et al., 2007; Duchemin et al., 2013). Several of the MFA that have been associated with $\mathrm{CH}_{4}$ emission (van Gastelen and Dijkstra, 2016) are also affected by DGAT1, in particular C18 UFA in both the cis and trans isomers.

The DGAT1 gene is expressed in the small intestine, liver, adipose tissue, and the mammary gland (DeVita and Pinto, 2013; Muise et al., 2014). Thus, effects of DGAT1 on traits other than milk production might be expected. S. van Engelen (Wageningen University \& Research; unpublished data) performed a genome-wide association study (GWAS) to determine regions of the bovine genome that are associated with predicted $\mathrm{CH}_{4}$ yield $\left(\mathrm{g} / \mathrm{kg}\right.$ of DMI) using the $\mathrm{CH}_{4}$ prediction equations based on MFA profile published by Dijkstra et al. (2011) and Van Engelen et al. (2015). The association with DGAT1 was significant in the GWAS for predicted $\mathrm{CH}_{4}$ yield, suggesting that the DGAT1 $\mathrm{K}$ allele is associated with higher predicted $\mathrm{CH}_{4}$ yield. The association between DGAT1 and $\mathrm{CH}_{4}$ yield has not been studied before and could be of statistical and biological significance. To the best of our knowledge, no study has investigated if the genetic variation of dairy cows, namely DGAT1, affects the rumen bacterial and archaeal composition, one of the potential biological explanations for the relation between DGAT1 and $\mathrm{CH}_{4}$ yield. In addition, little information is available on the association of DGAT1 with nutrient digestion or energy and $\mathrm{N}$ balance of dairy cattle.

Therefore, the objectives of the present study were to investigate the effects of dietary linseed oil, DGAT1, and the interaction between dietary linseed oil and DGAT1 on $\mathrm{CH}_{4}$ and $\mathrm{H}_{2}$ emission, energy and $\mathrm{N}$ metabolism, lactation performance, ruminal fermentation, and rumen bacterial and archaeal composition of dairy cows.

\section{MATERIALS AND METHODS}

\section{Experimental Design}

The experiment was conducted from January to April 2015, in accordance with Dutch law and approved by the Animal Care and Use Committee of Wageningen University \& Research (Wageningen, the Netherlands). The experiment followed a crossover design with 2 dietary treatments and 24 lactating Holstein-Friesian cows (i.e., 12 cows with DGAT1 KK genotype and 12 cows with DGAT1 AA genotype; each group had 6 primiparous and 6 multiparous cows). The 12 cows with DGAT1 KK genotype were sired by 10 bulls, and the 12 cows with DGAT1 AA genotype were sired by 9 bulls. Additionally, 1 bull sired 2 cows with the DGAT1 KK genotype and 1 cow with DGAT1 AA genotype. At the start of the experiment, the cows with the DGAT1 KK genotype and DGAT1 AA genotype were, on average, $215 \pm 65$ and $216 \pm 68$ DIM (means \pm SD) and produced $23.9 \pm 5.66$ and $26.9 \pm 5.87 \mathrm{~kg}$ of milk/d, respectively. The cows were blocked in pairs according their DGAT1 genotype, parity, DIM, and milk production. Within each block, cows were randomly allocated to a dietary treatment sequence in a crossover design with 2 periods: a control diet $(\mathbf{C O N})$ and linseed oil diet (LSO). Treatment periods lasted $17 \mathrm{~d}$ and were composed of a 12-d adaptation period followed by a 5 -d measurement period. There was a 14-d wash-out period between the treatment periods of the same block of cows.

\section{Diets, Feeding, and Housing}

Both the CON and LSO diet consisted of $40 \%$ corn silage, $30 \%$ grass silage, and $30 \%$ concentrates on a DM basis. The ingredient and chemical composition of both diets are presented in Table 1. Linseed oil (Linagro NV, Lichtervelde, Belgium) was added to the concentrate of 
the LSO diet, substituting a part of the CON concentrate ingredients, to achieve a difference of $22 \mathrm{~g} / \mathrm{kg}$ of $\mathrm{DM}$ in fat content between the 2 diets. To determine apparent total-tract feed digestibility, $\mathrm{Cr}_{2} \mathrm{O}_{3}(1.5 \mathrm{~g} / \mathrm{kg}$ of concentrate DM) was included in the concentrates of both diets as an external marker. Concentrates were produced by Research Diet Services (RDS BV, Wijk bij Duurstede, the Netherlands) in 1 batch and hence were assumed to be of uniform composition throughout the experiment. Diets were formulated to meet the requirements for maintenance and milk production of the lactating dairy cows. The $\mathrm{NE}_{\mathrm{L}}$ was calculated with the VEM (feed unit lactation) system according to Van Es (1978), and intestinal digestible protein and rumen degradable protein balance were calculated according to Van Duinkerken et al. (2011).

Cows were fed and milked at 0600 and $1600 \mathrm{~h}$. Just before milking, the feed refusals were weighed and a new portion of the diet provided. The diets were fed as a TMR in 2 equal daily portions. The concentrate was provided in meal form and manually mixed into the roughage mixture at the time of feeding. Cows had free access to clean drinking water throughout the experiment. Cows were fed individually and feed refusals were collected to determine DMI throughout the experiment. Cows were fed ad libitum during the first $8 \mathrm{~d}$ of the adaptation period. From d 9 onward, feed intake was restricted per block to $95 \%$ of the ad libitum DMI of the cow within a block consuming the lowest amount of feed during $d 5$ to $d 8$ as described previously by van Zijderveld et al. (2011a). The cows were fed restricted amounts of feed to avoid confounding effects of DMI on enteric $\mathrm{CH}_{4}$ production, similar to van Zijderveld et al. (2011a). At all times, a minimum DMI of at least $82 \%$ of the ad libitum intake of the cow with the greatest DMI within each block was ensured.

During the 12-d adaptation period, the cows were individually housed in tiestalls to become accustomed to the diet and restriction in movement. On d 13 (1400 h), after the adaptation period, 4 cows (2 blocks) were

Table 1. Chemical composition ( $\mathrm{g} / \mathrm{kg}$ of DM, unless otherwise stated) of the TMR ingredients (grass silage, corn silage, concentrates; analyzed) and of the complete TMR (calculated) for the control diet (CON) and linseed oil (LSO) diet

\begin{tabular}{|c|c|c|c|c|c|c|}
\hline \multirow[b]{2}{*}{ Item } & \multicolumn{2}{|c|}{ Silage } & \multicolumn{2}{|c|}{ Concentrate } & \multicolumn{2}{|c|}{ TMR } \\
\hline & Grass $^{1}$ & Corn $^{2}$ & $\mathrm{CON}^{3}$ & $\mathrm{LSO}^{4}$ & $\mathrm{CON}^{5}$ & $\mathrm{LSO}^{6}$ \\
\hline DM (g/kg of product) & 558 & 318 & 878 & 890 & 468 & 469 \\
\hline $\mathrm{OM}$ & 911 & 959 & 880 & 889 & 921 & 924 \\
\hline $\mathrm{CP}$ & 140 & 83 & 394 & 361 & 194 & 184 \\
\hline Crude fat & 33 & 34 & 33 & 108 & 34 & 56 \\
\hline Gross energy (MJ/kg of DM) & 18.3 & 18.4 & 18.0 & 19.7 & 18.2 & 18.7 \\
\hline $\mathrm{NDF}$ & 546 & 330 & 203 & 178 & 357 & 349 \\
\hline $\mathrm{ADF}$ & 303 & 185 & 101 & 91 & 195 & 192 \\
\hline ADL & 15 & 9 & 17 & 16 & 13 & 13 \\
\hline Starch & $-^{7}$ & 373 & 18 & 14 & 154 & 153 \\
\hline Reducing sugars & 88 & $-^{7}$ & 137 & 124 & 67 & 63 \\
\hline \multicolumn{7}{|l|}{ Fatty acids } \\
\hline C16:0 & 2.7 & 2.7 & 2.4 & 7.1 & 2.6 & 4.0 \\
\hline $\mathrm{C} 18: 0$ & 0.26 & 0.44 & 0.48 & 2.9 & 0.40 & 1.1 \\
\hline C18:1 cis-9 & 0.30 & 3.2 & 3.8 & 17.9 & 2.5 & 6.8 \\
\hline $\mathrm{C} 18: 2 \mathrm{n}-6$ & 2.3 & 8.3 & 6.8 & 19.7 & 6.1 & 9.9 \\
\hline C18:3n-3 & 8.5 & 1.0 & 1.0 & 35.4 & 3.2 & 13.5 \\
\hline Total fatty acids & 16.2 & 16.1 & 14.4 & 86.8 & 15.6 & 37.3 \\
\hline
\end{tabular}

${ }^{1} \mathrm{NE}_{\mathrm{L}}=6.2 \mathrm{MJ} / \mathrm{kg}$ of DM; intestinal digestible protein (DVE) $=64 \mathrm{~g} / \mathrm{kg}$ of DM; rumen-degraded protein balance $(\mathrm{OEB})=11 \mathrm{~g} / \mathrm{kg}$ of DM; ensiling characteristics: acetic acid $=9 \mathrm{~g} / \mathrm{kg}$ of DM, lactic acid $=13 \mathrm{~g} / \mathrm{kg}$ of $\mathrm{DM}$, ammonia- $\mathrm{N}=6 \%$ of total $\mathrm{N}$, and $\mathrm{pH}=5.9$.

${ }^{2} \mathrm{NE}_{\mathrm{L}}=7.0 \mathrm{MJ} / \mathrm{kg}$ of DM; DVE $=56 \mathrm{~g} / \mathrm{kg}$ of DM; OEB $=-8 \mathrm{~g} / \mathrm{kg}$ of DM; ensiling characteristics: acetic acid $=11 \mathrm{~g} / \mathrm{kg}$ of DM, lactic acid $=55 \mathrm{~g} / \mathrm{kg}$ of DM, ammonia- $\mathrm{N}=8 \%$ of total $\mathrm{N}$, and $\mathrm{pH}=3.7$.

${ }^{3}$ Concentrate added to the CON diet contained $(\mathrm{g} / \mathrm{kg}$ of $\mathrm{DM})$ : soybean meal $=400$, soybean meal, formaldehyde treated $=200$, rapeseed meal $=100$, rapeseed meal, formaldehyde treated $=100$, sugar beet pulp $=119$, sugarcane molasses $=40, \mathrm{CaCO}_{3}=15, \mathrm{NaCl}=8.0, \mathrm{NaHCO}_{3}=2.0$, trace mineral and vitamin mix $=8.0$, $\mathrm{MgO}=7.0$, and $\mathrm{Cr}_{2} \mathrm{O}_{3}=1.5$.

${ }^{4}$ Concentrate added to the LSO diet contained $(\mathrm{g} / \mathrm{kg}$ of DM): soybean meal $=369$, soybean meal, formaldehyde treated $=184$, rapeseed meal $=92$, rapeseed meal, formaldehyde treated $=92$, sugar beet pulp $=109$, sugarcane molasses $=37, \mathrm{CaCO}_{3}=15, \mathrm{NaCl}=8.0, \mathrm{NaHCO}_{3}=2.0$, trace mineral and vitamin mix $=8.0, \mathrm{MgO}=$ 7.0, $\mathrm{Cr}_{2} \mathrm{O}_{3}=1.5$, and linseed oil (Linagro NV, Lichtervelde, Belgium) $=76$.

${ }^{5}$ TMR contained grass silage, $300 \mathrm{~g} / \mathrm{kg}$ of DM; corn silage, $400 \mathrm{~g} / \mathrm{kg}$ of DM; CON concentrate, $300 \mathrm{~g} / \mathrm{kg}$ of DM. ${ }^{6} \mathrm{TMR}$ contained grass silage, $300 \mathrm{~g} / \mathrm{kg}$ of DM; corn silage, $400 \mathrm{~g} / \mathrm{kg}$ of DM; LSO concentrate, $300 \mathrm{~g} / \mathrm{kg}$ of DM. ${ }^{7}$ Not determined. 
individually transported to 1 of 4 identical climate respiration chambers (CRC), located approximately $200 \mathrm{~m}$ from the tiestalls, for a 5-d period to determine gaseous exchange, energy and $\mathrm{N}$ balance, and apparent total-tract nutrient digestibility. A detailed description of the CRC design and gas measurements is reported by Heetkamp et al. (2015) and van Gastelen et al. (2015). Briefly, in each CRC (i.e., an area of $11.8 \mathrm{~m}^{2}$ and a volume of $34.5 \mathrm{~m}^{3}$ ), relative humidity was maintained at $65 \%$ and temperature at $16^{\circ} \mathrm{C}$. The $\mathrm{CRC}$ were equipped with thin walls with windows, to allow audio-visual contact to minimize the effect of social isolation on cow behavior and performance. Cows were exposed to $16 \mathrm{~h}$ of light per day (from 0530 to $2130 \mathrm{~h}$ ) and housed in the CRC until d 17 (0900 h).

In addition to van Gastelen et al. (2015), a $\mathrm{H}_{2}$ analyzer (type MGA 3000 multi gas analyzer, ADC Gas Analysis Ltd., Hoddesdon, UK) was installed in series with the $\mathrm{O}_{2}, \mathrm{CO}_{2}$, and $\mathrm{CH}_{4}$ gas analyzers. The $\mathrm{H}_{2}$ concentrations were measured using an electrochemical cell technique, which has a relatively slow response time compared with the nondispersive infrared method of the $\mathrm{CO}_{2}$ and $\mathrm{CH}_{4}$ gas analyzers and the paramagnetic method of the $\mathrm{O}_{2}$ gas analyzer. Therefore, sampled air from the CRC was flushed through the gas analysis system for $180 \mathrm{~s}$ before the analyzer readout was logged. To have as many measurements as possible, inlet air was not sampled in every sequence, but once per hour. Therefore, inlet and exhaust air of each CRC was sampled with an average interval of 12.5 min (i.e., 4 times 12-min intervals for each CRC and 1 interval of $15 \mathrm{~min}$ for inlet air) instead of the 10-min interval reported by van Gastelen et al. (2015). Production of $\mathrm{CO}_{2}, \mathrm{H}_{2}$, and $\mathrm{CH}_{4}$ and consumption of $\mathrm{O}_{2}$ was calculated from the difference between inlet and exhaust gas volumes.

The ventilation rate within the CRC was $58 \mathrm{~m}^{3} / \mathrm{h}$ to ensure that the $\mathrm{H}_{2}$ peak after feeding was within the detection limit of the $\mathrm{H}_{2}$ analyzer (i.e., 0-100 ppm). Staff entered the CRC twice daily at 0600 and $1600 \mathrm{~h}$ for approximately $30 \mathrm{~min}$ for feeding and milking. van Gastelen et al. (2015) did not use the gas concentration data during these feeding and milking times. The $\mathrm{H}_{2}$ concentration peak occurred directly after feeding when staff was still inside the CRC. Therefore, we calculated the daily $\mathrm{CH}_{4}$ and $\mathrm{H}_{2}$ production on 2 data sets: (1) without the gas concentration data during feeding/ milking (as was done by van Gastelen et al. (2015), partially missing the $\mathrm{H}_{2}$ concentration peak after feeding), and (2) with the gas concentration data during feeding/milking (to capture the $\mathrm{H}_{2}$ concentration peak directly after feeding). Excluding the gas concentration measurements during feeding/milking would have underestimated daily $\mathrm{H}_{2}$ production by $15.2 \pm 6.89 \%$. Daily productions of $\mathrm{CH}_{4}$ were unaffected when exclud- ing these gas measurements compared with including these gas measurements (data not shown). Thus, for the present study it was decided to not discard the gas measurements during feeding and milking.

Gas concentrations and ventilation rates were corrected for pressure, temperature, and relative humidity to arrive at standard temperature pressure dew point volumes of inlet and exhaust air. Once a day, calibration gasses were sampled for gas analysis instead of the inlet air, and the analyzed and actual values of these calibration gasses were used to correct the measured gas concentrations from the inlet air and exhaust air of all compartments. Before the present experiment started, CRC were checked by releasing known amounts of $\mathrm{CO}_{2}$ in each compartment and comparing these values with the data from the gas analysis system to calculate the recovery. The recovered amounts of $\mathrm{CO}_{2}$ were between 99 and $101 \%$.

\section{Sample Collection and Measurements}

Samples of grass silage, corn silage, and both concentrates were obtained when fresh feed was prepared (i.e., twice weekly). These samples were subsequently pooled per treatment period, subsampled, and stored at $-20^{\circ} \mathrm{C}$ pending analyses. During the 5 -d period in the CRC, feed residues were collected twice daily (0600 and $1600 \mathrm{~h}$ ), weighed, and stored at $4^{\circ} \mathrm{C}$. At the end of the 5 -d period in the CRC, daily orts were pooled per cow, mixed, subsampled, and stored at $-20^{\circ} \mathrm{C}$ pending analyses.

Rumen fluid samples ( $\sim \mathrm{L}$ ) were collected $1 \mathrm{~h}$ before and $4 \mathrm{~h}$ after morning feeding on $\mathrm{d} 12$ and $4 \mathrm{~h}$ after morning feeding on d 17 using the oral stomach tube (OST) technique, similar to Shen et al. (2012). Rumen fluid samples could not be collected $1 \mathrm{~h}$ before morning feeding on $\mathrm{d} 17$, because the cows were still housed in the CRC and the gas measurements were priority. To collect rumen fluid with the OST method, a probe was inserted in the ventral cranial part of the rumen via the esophagus. The probe was $190 \mathrm{~cm}$ long and the head of the probe consisted of small holes allowing only rumen fluid (i.e., no fibrous content) to be collected. Rumen fluid was collected by using a 500-mL suction pump, which was attached to the probe. The first $500 \mathrm{~mL}$ of rumen fluid was discarded to limit saliva contamination of the rumen fluid samples. Rumen $\mathrm{pH}$ was measured immediately after sampling using a calibrated portable electronic $\mathrm{pH}$ meter ( $\mathrm{pH}$ electrode HI99141, Hanna Instruments, IJsselstein, the Netherlands) and 2 rumen fluid subsamples of $600 \mu \mathrm{L}$ each were acidified with an equal volume of ortho-phosphoric acid, and directly stored at $-20^{\circ} \mathrm{C}$ to stop microbial fermentation pending VFA analysis. On d 17, $4 \mathrm{~h}$ after morning feeding, 
$100 \mathrm{~mL}$ of rumen fluid was sampled, directly stored on dry ice, and transferred to a $-80^{\circ} \mathrm{C}$ freezer pending microbiota analysis.

Milk yield was recorded for each milking, both during the adaptation period in the tiestalls and the measurement period in the CRC. Milk from cows in the CRC was collected twice daily at 0600 and $1600 \mathrm{~h}$. A milk sample $(10 \mathrm{~mL})$ of each milking event was collected in a tube containing sodium azide $(5 \mu \mathrm{L})$ for preservation, stored no longer than $4 \mathrm{~d}$ at $4^{\circ} \mathrm{C}$, and analyzed for fat, protein, lactose, and urea content. Milk composition was corrected for differences in milk yield between milking events on the same day, and the average milk composition on a daily basis was used for data analysis. An additional milk sample (5 $\mathrm{g} / \mathrm{kg}$ of milk) was collected at each milking event, pooled per cow for the entire period in the CRC, and stored at $-20^{\circ} \mathrm{C}$ pending milk energy and $\mathrm{N}$ analyses. For MFA composition, milk samples were collected according to van Gastelen et al. (2015), pooled per cow per period, and stored at $-20^{\circ} \mathrm{C}$ until analyses.

Measurements of $\mathrm{CH}_{4}, \mathrm{H}_{2}$, and $\mathrm{CO}_{2}$ production, and $\mathrm{O}_{2}$ consumption were based on data recorded from $\mathrm{d}$ $14(0800 \mathrm{~h})$ through d $17(0800 \mathrm{~h})$, whereas energy and $\mathrm{N}$ balance, and apparent total-tract feed digestibility were based on manure (mixture of feces and urine) and feces collections from d $13(1400 \mathrm{~h})$ through d 17 (0900 $\mathrm{h})$. Cows were weighed when entering and leaving of the CRC. The feces and urine produced during the 5 -d period in the CRC were quantitatively collected, weighed, mixed, subsampled, and stored at $-20^{\circ} \mathrm{C}$ pending analyses. In addition, samples of condensed water (i.e., collected from the heat exchanger) and $25 \%$ sulfuric acid solution wt/wt (i.e., through which the outflowing air was led to trap aerial ammonia) of each CRC were collected, because of $\mathrm{N}$ volatilization in the form of ammonia due to the mixing of feces and urine. During the $5 \mathrm{~d}$ in the CRC, rectal grab samples $(\sim 300$ g) were collected twice daily at 0600 and $1600 \mathrm{~h}$ and stored at $-20^{\circ} \mathrm{C}$. Prior to analysis, the grab samples were thawed, pooled per cow and period, mixed, and subsampled.

\section{Chemical Analyses}

Samples of feed, feed residues, manure, and rectal grab samples were thawed at room temperature, ovendried at $60^{\circ} \mathrm{C}$, ground to pass a $1-\mathrm{mm}$ screen using a Wiley mill (Peppink 100AN, Olst, the Netherlands), and analyzed by wet chemistry [i.e., ash, DM, N, starch, reducing sugars (i.e., all carbohydrates with reducing properties and soluble in $40 \%$ ethanol), NDF, ADF, and ADL] as described by Abrahamse et al. (2008). Bomb calorimetry (ISO 9831; International Organiza- tion for Standardization, 1998) was used to determine gross energy (GE). Crude protein was calculated as $\mathrm{N} \times 6.25$, where $\mathrm{N}$ was determined using the Kjeldahl method with $\mathrm{CuSO}_{4}$ as catalyst (ISO 5983; International Organization for Standardization, 2005). The $\mathrm{N}$ concentrations in manure and of roughages were determined in fresh material according to Klop et al. (2016). The FAME of the feed samples were determined as described by Khan et al. (2009) using GC (Carlo Erba 8560 HRGC, Rodano, Italy) with a fused silica capillary column $(100 \mathrm{~m} \times 0.250 \mathrm{~mm}$ and $0.2 \mu \mathrm{m}$ film thickness; SP-2560, Supelco, St. Louis, MO) and helium as the carrier gas. Crude fat content was analyzed according the gravimetric method NEN-ISO 1735 (ISO 1735; International Organization for Standardization, 2004a) with modifications as described by Klop et al. (2017).

Grass silage, corn silage, and concentrates were analyzed for DM, ash, N, crude fat, starch (except for grass silage), sugars (except for corn silage), NDF, ADF, ADL, GE, and FAME. Feed residues were analyzed for DM, ash, and crude fat. Manure samples were analyzed for DM, N, and GE. The rectal grab samples were analyzed for DM, ash, N, crude fat, starch, NDF, and GE. Chromium oxide was determined in the concentrates and rectal grab samples using an atomic absorption spectrophotometer (AA240FS, Varian, Palo Alto, CA) after oxidation by wet destruction as described in detail by Pellikaan et al. (2013).

The concentration of individual VFA in the rumen fluid samples of d 12 (i.e., $1 \mathrm{~h}$ before and $4 \mathrm{~h}$ after morning feeding) was determined using GC (Fisons HRGC Mega 2, CE Instruments, Milan, Italy) with a split/splitless injector and helium as carrier gas as described by van Gastelen et al. (2015). Milk samples from individual milking events were analyzed for proximate composition (fat, protein, and lactose content) by mid-infrared spectroscopy (ISO 9622; International Organization for Standardization, 1999), and for MUN using the $\mathrm{pH}$ difference technique (ISO 14637; International Organization for Standardization, 2004b) at Qlip (Zutphen, the Netherlands). The MFA composition of the pooled milk samples was determined using GC (Thermo Electron Corporation, Waltham, MA) by Qlip with a split/splitless injector and $\mathrm{H}_{2}$ as carrier gas as described by van Gastelen et al. (2015). The GE and $\mathrm{N}$ content of the pooled milk samples were analyzed as described above.

\section{Microbiota Analysis}

Rumen fluid samples taken $4 \mathrm{~h}$ after morning feeding on d 17 were analyzed for bacterial and archaeal concentrations and community composition, using quanti- 
tative PCR (qPCR) and Illumina MiSeq sequencing of PCR-amplified 16S ribosomal RNA (rRNA) gene fragments. Total DNA was extracted from the rumen fluid samples using a protocol involving a combination of bead beating, stool transport and recovery buffer (Roche Diagnostics Nederland B.V, Almere, the Netherlands), and the Maxwell 16 Instrument (Promega, Leiden, the Netherlands) as described in detail by van Lingen et al. (2017). For absolute quantification of bacteria and archaea, SYBR green qPCR assays were performed with sample DNA extracts using an iCycler iQ real-time detection system (Bio-Rad Laboratories B.V., Veenendaal, the Netherlands). The qPCR procedure, primers, cycling conditions, and standards used are described by van Lingen et al. (2017). For combined bacterial and archaeal composition profiling, barcoded amplicons from the V4 region of $16 \mathrm{~S}$ rRNA genes were generated from sample DNA extracts using a 2-step PCR strategy (Caporaso et al., 2012; Tian et al., 2016; van Lingen et al., 2017). As described by Ramiro-Garcia et al. (2016), the 16S rRNA gene sequencing data were analyzed using NG-Tax, an in-house bioinformatics pipeline. Operational taxonomic units (OTU) were defined using an open reference approach, and taxonomy was assigned to those OTU using a SILVA $16 \mathrm{~S}$ rRNA gene reference database (Quast et al., 2013). Preliminary analysis of the samples confirmed the necessity of excluding 3 of the rumen fluid samples from further microbial data analysis (i.e., both sequence and qPCRbased analysis) due to issues associated with salivary contamination of the samples during collection.

\section{Statistical Analysis}

All parameters related to feed intake, milk production, and milk composition while cows were housed in the CRC were averaged per cow over a 4-d period. The parameters related to energy and $\mathrm{N}$ balance were expressed per kilogram of metabolic BW $\left(\mathrm{BW}^{0.75}\right)$ per day. All univariate data were subjected to ANOVA in a crossover with a 2 period $\times 2$ treatment design using the MIXED procedure in SAS (edition 9.2, SAS Institute Inc., Cary, NC). Treatments (i.e., diet and $D G A T 1$ ), their interaction, diet sequence, and period were considered fixed effects. The model included block as random factor, and cow within diet $\times D G A T 1$ was considered as subject. For all analyses, the fixed effect of CRC was initially included in the model, but was removed because it was found to be not significant. The fixed effect of diet sequence was found to be significant twice (i.e., MUN and C22:0) and a tendency was found once (i.e., C22:4n-6), but diet sequence was always kept in the model. The covariance structure compound symmetry provided best fit with the lowest overall Akaike's information criterion values. Ruminal VFA data were subjected to repeated measures ANOVA to take repeated sampling within the same cow per treatment period into account. Similar to the above described model, this model included treatments, their interactions, sequence, and period as fixed effects, and block as random effect. Again, the fixed effect of diet sequence was found to be significant once (i.e., total VFA concentration) and a tendency was found twice (i.e., molar proportions of acetate and butyrate), but diet sequence was always kept in the model. For both models, pairwise comparisons of means were tested with the Tukey-Kramer method. The Kenward-Roger option was used to estimate the denominator degrees of freedom. All results are reported as least squares means with significance of effects declared at $P \leq 0.05$ and trends at $0.05<P \leq 0.10$. No multiple testing correction was applied.

Permutational multivariate analysis of variance (PERMANOVA; Anderson, 2001) was used to assess the significance of changes in the rumen bacterial and archaeal composition in terms of the microbiota as a whole community (with the OTU summarized to the genus level) with respect to different factors [i.e., diet (LSO and CON), DGAT1 (DGAT1 KK and AA genotype), and diet $\times D G A T 1]$. The PERMANOVA was applied on the Bray-Curtis distance matrices, and Bonferroni correction for multiple testing was applied on a nominal significance of 0.05. The Matlab Fathom toolbox (Jones, 2015) was used for calculations. The aforementioned ANOVA analysis was also used to determine the effect of diet, DGAT1, and diet $\times D G A T 1$ interaction on the relative abundance of individual bacterial and archaeal genera that were (1) consistent in all animals and (2) were $>0.05 \%$ in terms of relative abundance.

\section{RESULTS AND DISCUSSION}

\section{Intake and Digestibility of Nutrients}

Nutrient intake, DMI, fatty acid (FA) intake, and apparent total-tract digestibility of nutrients were not affected by DGAT1 polymorphism and diet $\times D G A T 1$ interaction. Feeding the LSO diet resulted in an increased crude fat intake $(P<0.001)$, intake of individual FA $(P<0.001)$, and intake of total FA $(P<$ 0.001) compared with the CON diet (Table 2). These results are in line with the difference in chemical composition between the LSO diet and CON diet; linseed oil increased the dietary fat content from 34 to $56 \mathrm{~g} /$ $\mathrm{kg}$ of DM (Table 1). The LSO diet (2.3\% linseed oil on DM basis) increased apparent total-tract digestibility of crude fat compared with the CON diet $(P<0.001)$, 
Table 2. The effect of DGAT1 K232A polymorphism (AA or KK) on intake and apparent total-tract digestibility of nutrients of lactating dairy cows fed diets with (LSO) or without (CON) linseed oil

\begin{tabular}{|c|c|c|c|c|c|c|c|c|}
\hline \multirow[b]{2}{*}{ Item } & \multicolumn{2}{|c|}{ Diet } & \multicolumn{2}{|c|}{$D G A T 1$ genotype } & \multirow[b]{2}{*}{ SEM } & \multicolumn{3}{|c|}{$P$-value } \\
\hline & $\mathrm{CON}$ & LSO & $\mathrm{AA}$ & KK & & Diet & $D G A T 1$ & Diet $\times D G A T 1$ \\
\hline DM & 18.0 & 17.5 & 17.8 & 17.6 & 0.69 & 0.649 & 0.825 & 0.935 \\
\hline $\mathrm{OM}$ & 16.5 & 16.2 & 16.5 & 16.3 & 0.63 & 0.686 & 0.825 & 0.934 \\
\hline $\mathrm{CP}$ & 3.48 & 3.22 & 3.37 & 3.33 & 0.130 & 0.165 & 0.927 & 0.939 \\
\hline Crude fat & 0.60 & 0.99 & 0.80 & 0.79 & 0.032 & $<0.001$ & 0.817 & 0.892 \\
\hline $\mathrm{ADF}$ & 3.50 & 3.36 & 3.45 & 3.41 & 0.133 & 0.450 & 0.826 & 0.936 \\
\hline ADL & 0.24 & 0.23 & 0.24 & 0.23 & 0.009 & 0.379 & 0.823 & 0.936 \\
\hline Starch & 2.77 & 2.68 & 2.75 & 2.71 & 0.106 & 0.557 & 0.825 & 0.936 \\
\hline Reducing sugars & 1.21 & 1.11 & 1.17 & 1.15 & 0.045 & 0.134 & 0.824 & 0.939 \\
\hline \multicolumn{9}{|l|}{ Fatty acid intake (g/d) } \\
\hline C16:0 & 46.7 & 70.6 & 59.0 & 58.3 & 2.34 & $<0.001$ & 0.816 & 0.899 \\
\hline C18:0 & 7.1 & 19.7 & 13.5 & 13.3 & 0.59 & $<0.001$ & 0.816 & 0.866 \\
\hline DM & 78.8 & 79.2 & 79.4 & 78.6 & 0.54 & 0.626 & 0.306 & 0.786 \\
\hline $\mathrm{OM}$ & 80.3 & 80.8 & 80.9 & 80.2 & 0.49 & 0.553 & 0.344 & 0.635 \\
\hline $\mathrm{CP}$ & 77.0 & 77.0 & 77.3 & 76.7 & 0.58 & 0.999 & 0.422 & 0.687 \\
\hline Crude fat & 68.8 & 77.1 & 73.8 & 72.1 & 0.93 & $<0.001$ & 0.203 & 0.975 \\
\hline Gross energy & 78.3 & 79.0 & 79.0 & 78.2 & 0.52 & 0.373 & 0.267 & 0.576 \\
\hline NDF & 70.8 & 71.0 & 71.6 & 70.2 & 0.82 & 0.858 & 0.215 & 0.498 \\
\hline Starch & 99.0 & 99.0 & 99.0 & 99.0 & 0.04 & 0.999 & 0.999 & 0.165 \\
\hline
\end{tabular}

but the apparent total-tract digestibility of the other nutrients was unaffected (Table 2). The increased crude fat digestibility of the LSO diet may have been the result of UFA from linseed having a higher total-tract digestibility than SFA (van Zijderveld et al., 2011b). Several studies also reported the effect of linseed oil on apparent total-tract digestibility of nutrients, but the results reported are variable. Similar to this study, Benchaar et al. (2012) did not find an effect of adding increasing amounts of linseed oil to the diet [i.e., grass silage and corn silage; 50:50 forage-to-concentrate ratio (F:C); DM basis] on apparent total-tract digestibility of DM, OM, CP, NDF, starch, and GE. Martin et al. (2008), however, observed decreased DM, OM, and NDF digestibility when supplementing $5.7 \%$ linseed oil to a forage-rich diet (i.e., corn silage and grass hay; 65:35 F:C; DM basis). Ueda et al. (2003) reported an increase in OM and NDF digestibility when $3 \%$ linseed oil was added to a forage rich diet (i.e., grass hay; 65:35 F:C; DM basis), whereas the digestibility of these nutrients decreased when $3 \%$ linseed oil was added to a concentrate rich diet (35:65 F:C; DM basis). Benchaar et al. (2015) observed a decreased DM, OM, NDF, and GE digestibility when $4 \%$ linseed oil was added to a corn-silage-based diet (60:40 F:C; DM basis), whereas DM, OM, and GE digestibility increased and NDF digestibility was unaffected when linseed oil was supplemented to a red-clover-silage-based diet (60:40 F:C; DM basis). Taken together, these results suggest that the effect of linseed oil on nutrient digestibility may vary with the source of forage in the basal diet, the forage to concentrate ratio, as well as the amount of linseed oil added.

\section{Lactation Performance and Milk Fatty Acid Profile}

No diet $\times D G A T 1$ interaction effect on milk production and milk composition was observed. Compared with the DGAT1 AA genotype, the DGAT1 KK genotype was associated with a higher milk fat and protein content $(P<0.001$ and $P=0.005$, respectively; Table 3 ), and tended to have a lower milk yield and lactose yield. The FPCM yield did not differ between the DGAT1 KK and DGAT1 AA genotype, which is consistent with a similar DMI, nutrient intake, and gross energy intake (GEI) between the 2 DGAT1 genotypes. The major effect of DGAT1 on milk production traits has been often observed, with the $\mathrm{K}$ allele associated with a higher milk fat and protein content, but lower milk production than the A allele (e.g., Schennink et al., 2007; Bovenhuis et al., 2015), which is in line with the present study. Many studies also reported the $\mathrm{K}$ allele to be associated with a higher fat yield and lower protein yield, although the reduced protein yield is not 
Table 3. The effect of DGAT1 K232A polymorphism (AA or KK) on milk production and milk composition of lactating dairy cows fed diets with (LSO) or without (CON) linseed oil

\begin{tabular}{|c|c|c|c|c|c|c|c|c|}
\hline \multirow[b]{2}{*}{ Item } & \multicolumn{2}{|c|}{ Diet } & \multicolumn{2}{|c|}{$D G A T 1$ genotype } & \multirow[b]{2}{*}{ SEM } & \multicolumn{3}{|c|}{$P$-value } \\
\hline & $\mathrm{CON}$ & LSO & $\mathrm{AA}$ & KK & & Diet & $D G A T 1$ & Diet $\times D G A T 1$ \\
\hline $\mathrm{FPCM}^{1}(\mathrm{~kg} / \mathrm{d})$ & 26.8 & 27.3 & 27.2 & 26.9 & 1.08 & 0.726 & 0.816 & 0.628 \\
\hline Milk fat content (\%) & 4.93 & 4.44 & 4.22 & 5.16 & 0.102 & 0.002 & $<0.001$ & 0.803 \\
\hline Milk protein content $(\%)$ & 3.66 & 3.48 & 3.44 & 3.70 & 0.063 & 0.045 & 0.005 & 0.529 \\
\hline Milk lactose content (\%) & 4.64 & 4.68 & 4.68 & 4.63 & 0.033 & 0.384 & 0.347 & 0.991 \\
\hline Lactose yield $(\mathrm{g} / \mathrm{d})$ & 1,121 & 1,229 & 1,251 & 1,099 & 55.9 & 0.171 & 0.058 & 0.728 \\
\hline MUN (mg/dL) & 13.3 & 7.8 & 10.9 & 10.2 & 0.39 & $<0.001$ & 0.195 & 0.652 \\
\hline
\end{tabular}

${ }^{1}$ Fat- and protein-corrected milk $=(0.337+0.116 \times$ fat $\%+0.06 \times$ protein $\%) \times$ milk yield $(\mathrm{kg} / \mathrm{d})$.

consistently reported (e.g., Näslund et al., 2008). This is not confirmed by the results of the present study (Table 3). In the present study, compared with the DGAT1 AA genotype, fat yield of the DGAT1 KK genotype was only numerically higher (1,180 vs. $1,102 \mathrm{~g} / \mathrm{d})$ and protein yield numerically lower (874 vs. $900 \mathrm{~g} / \mathrm{d}$ ).

The LSO diet resulted in a decreased milk fat content, milk protein content, and MUN $(P<0.045$; Table $3)$. The decrease in milk protein content was also observed by Benchaar et al. (2012, 2015) and may be the result of a dilution effect rather than a direct negative effect of the increased dietary fat content (Schroeder et al., 2004), as the milk yield numerically increased and protein yield was unaffected by the linseed oil. The decreased MUN content may have been a consequence of the lower CP content of the LSO diet. In general, a decreased MUN content is associated with an improved milk N efficiency (Spek et al., 2013), and the significantly higher milk N efficiency with the LSO diet (27.5\%) compared with the CON diet (24.6\%; discussed in the Energy and Nitrogen Retention section) is in line with the decrease in MUN. The decrease in milk fat content in the present study is in agreement with Martin et al. (2008), Ferlay et al. (2013), and Benchaar et al. (2015), but in contrast to others (e.g., Benchaar et al., 2012; Livingstone et al., 2015). The response of milk fat content to linseed oil is the result of the balance between a decrease in de novo FA synthesis and an increase in exogenous FA uptake and secretion by the mammary gland (Schroeder et al., 2004). The UFA from linseed oil have been reported to inhibit ruminal fibrolytic activity and subsequently decrease production of acetate and butyrate, which are precursors of de novo synthesized short- and medium-chain MFA (Bauman and Griinari, 2003). Also, these dietary UFA and several trans FA, the latter formed from ruminal biohydrogenation of the UFA, are potent inhibitors of de novo milk fat synthesis in the mammary gland (Bauman et al., 2011). In turn, dietary UFA increase the content of long-chain UFA in milk (Schroeder et al., 2004; Benchaar et al., 2012). In the present study, the inhibitory effects of linseed oil on de novo synthesized FA is greater than the increase in long-chain FA in milk (Table 4).

A diet $\times D G A T 1$ interaction for the individual MFA C14:0 and C15:0 was observed (Table 4). Previously, Van Vuuren et al. (2013) also observed an interaction between DGAT1 and linseed oil supplementation for certain MFA, although these were different from the ones reported in the present study, namely C18:0 and C20:1n-11. In addition, compared with the DGAT1 AA genotype, the DGAT1 KK genotype was associated with a higher C14:1 cis-9, C16:0, C16:1 cis-9, C22:0, C24:0, and total SFA content $(P<0.034)$, and a lower iso C17:0, C18:1 cis-9, C18:1 cis-12, C18:2n-6, C18:3n-3, and total PUFA content $(P<0.030)$ in the milk (Table 4). These results are largely in agreement with data in the literature. According to Schennink et al. (2007), Van Arendonk et al. (2009), Duchemin et al. (2013), and Bovenhuis et al. (2016), the DGAT1 K allele is associated with a larger fraction of C16:0, and smaller fractions of C14:0 (also reported by $\mathrm{Lu}$ et al., 2015), and $\mathrm{C} 18$ UFA in milk. In addition, Duchemin et al. (2013) reported an increase in milk C14:1 cis-9, C16:1 cis-9, and total SFA, and a decrease in total milk UFA for the DGAT1 K allele. Furthermore, according to Van Arendonk et al. (2009), Lu et al. (2015), and Bovenhuis et al. (2016), the DGAT1 $\mathrm{K}$ allele is associated with increased contents of C15:0 and C17:0 in milk.

The LSO diet of the present study resulted in a lower content of short- and medium-chain fatty acids (SMCFA) in the milk, with the exceptions of C4:0 and C16:1 trans-9 (Table 4). These results are generally in line with Chilliard et al. (2009), Benchaar et al. (2012), and Saliba et al. (2014). As previously stated, dietary UFA and several trans FA are potent inhibitors of de novo milk fat synthesis in the mammary gland, and the UFA from the linseed oil potentially inhibit ruminal fibrolytic activity, thereby decreasing the precursors for 
Table 4. The effect of DGAT1 K232A polymorphism (AA or KK) on milk fatty acid (FA) composition of lactating dairy cows fed diets with (LSO) or without $(\mathrm{CON})$ linseed oil

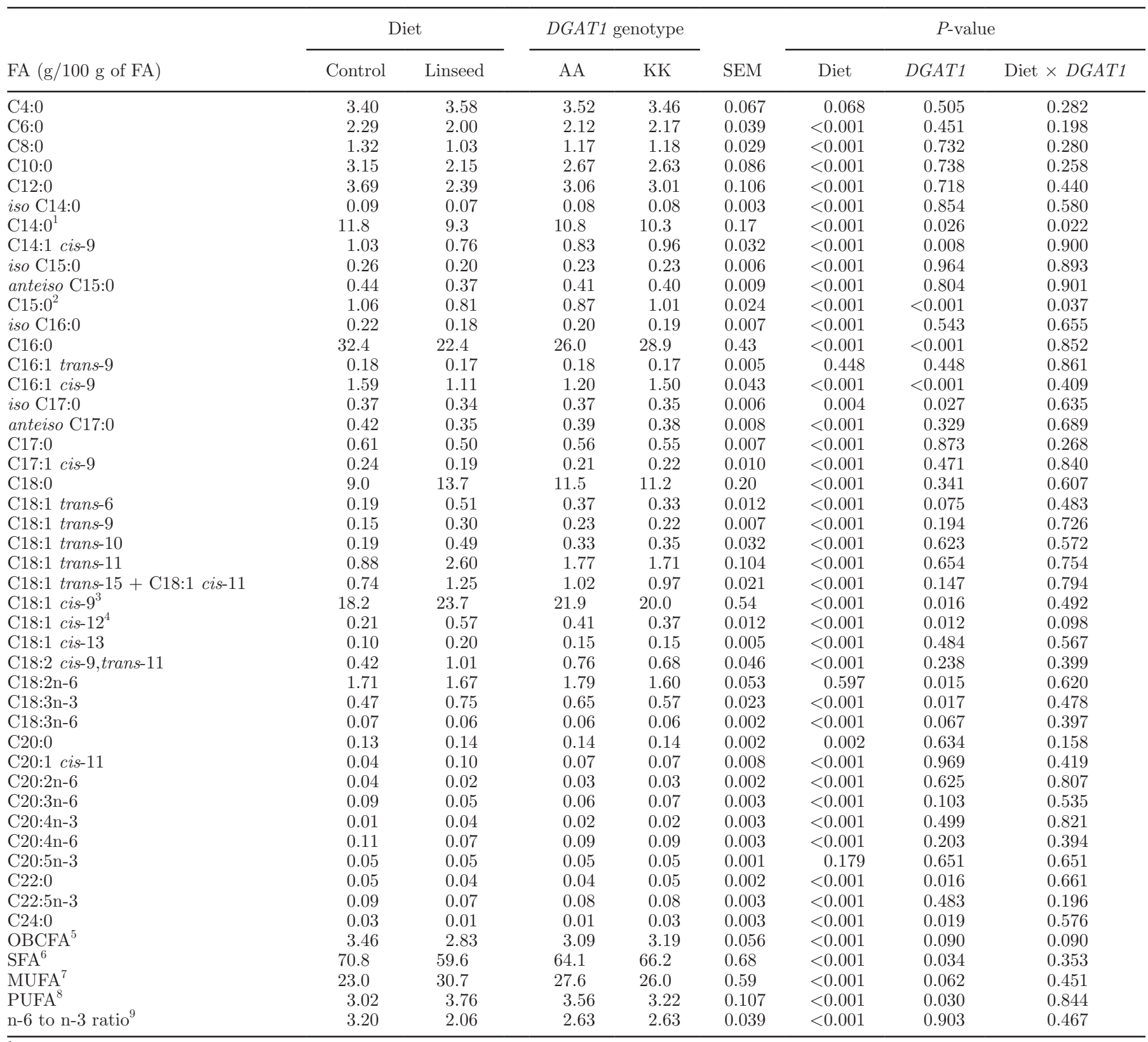

${ }^{1}$ Diet $\times$ DGAT1 interaction; CON AA $=12.35$, LSO AA $=9.33$, CON KK $=11.24$, LSO KK $=9.34$

${ }^{2}$ Diet $\times$ DGAT1 interaction; CON AA $=0.96$, LSO AA $=0.78$, CON KK $=1.17$, LSO KK $=0.84$.

${ }^{3} \mathrm{C} 18: 1$ cis-9 represents the sum of $\mathrm{C} 18: 1$ cis-9 and C18:1 trans-12, as these 2 FA could not be separated in the analysis. The portion of C18:1 trans-12 is considered to be negligible, as this FA is always present in small amounts.

${ }^{4}$ Diet $\times$ DGAT1 interaction; CON AA $=0.22, \mathrm{LSO} \mathrm{AA}=0.60, \mathrm{CON} \mathrm{KK}=0.20, \mathrm{LSO} \mathrm{KK}=0.53$.

${ }^{5}$ Sum of all odd- and branched-chain fatty acids (i.e., iso C14:0, iso C15:0, anteiso C15:0, C15:0, iso C16:0, iso C17:0, anteiso C17:0, and C17:0). Diet $\times$ DGAT1 interaction; CON AA $=3.36, \mathrm{LSO} \mathrm{AA}=2.83, \mathrm{CON} \mathrm{KK}=3.56, \mathrm{LSO} \mathrm{KK}=2.83$.

${ }^{6}$ Sum of all SFA.

${ }^{7}$ Sum of all MUFA.

${ }^{8}$ Sum of all PUFA.

${ }^{9}$ Ratio between the sum of all n-6 FA (i.e., C18:2n-6, C18:3n-6, C20:3n-6, and C20:4n-6) and the sum of all n-3 FA (i.e., C18:3n-3, C20:4n-3, C20:5n-3, and C22:5n-3) reported in this table. 
SMCFA synthesis (Bauman and Griinari, 2003). Milk SMCFA are synthesized de novo in the mammary gland primarily from acetate, and ruminal acetate proportion was decreased upon feeding linseed oil (discussed in the Ruminal Fermentation section). Only MFA C4:0 does not require acetate for its production as it can be produced directly from $\beta$-hydroxybutyrate derived from the blood (Bernard et al., 2008).

The LSO diet resulted in lower contents of all oddand branched-chain FA in milk compared the CON diet $(P<0.004$; Table 4). This is in line with Chilliard et al. (2009) and, in regard to C15:0 and C17:0, also with Benchaar et al. (2012). The odd-chain FA C15:0 and C17:0 are mainly synthesized de novo by ruminal bacteria from propionate. However, despite the increase in propionate proportions (Table 7), this ruminal synthesis of C15:0 and C17:0 may decrease when cows are fed dietary fat. This is because rumen bacteria preferably use preformed FA available in the ruminal environment (Byers and Schelling, 1988).

The intake of C18:3n-3 increased with the LSO diet $(P<0.001$; Table 2$)$. This increase is associated with an increase of $\mathrm{C} 18: 3 \mathrm{n}-3$, as well as the biohydrogenation intermediates (e.g., C18:1 trans-11) and end products (i.e., C18:0) in milk upon feeding linseed oil $(P<0.001$; Table 4), suggesting high levels of biohydrogenation, and is in line with Benchaar et al. (2012), Ferlay et al. (2013), and Livingstone et al. (2015). Despite the increased intake of C18:2n-6 with the LSO diet $(P<$ 0.001; Table 2), C18:2n-6 does not increase in milk upon feeding linseed oil, which is in agreement with Ferlay et al. (2013) and Saliba et al. (2014). Milk C18:2 cis9 ,trans-11 did increase with the LSO diet $(P<0.001$; Table 4), suggesting high levels of biohydrogenation of $\mathrm{C} 18: 2 \mathrm{n}-6$ in the rumen as well as increased endogenous production of C18:2 cis-9,trans-11 in the mammary gland using C18:1 trans-11 produced in the rumen as substrate (Griinari et al., 2000).

In the present study, both $\mathrm{C} 18: 1$ trans-10 and C18:1 trans-11 increased with the LSO diet $(P<0.001$; Table 4), which is consistent with Benchaar et al. (2012) and Saliba et al. (2014). The increase in C18:1 trans-11 content in milk may be the result of its production during the biohydrogenation of dietary $\mathrm{C} 18: 2 \mathrm{n}-6$ and C18:3n-3. An increase in C18:1 trans-10 in milk is generally associated with milk fat depression, and occurs when low fiber diets or diets supplemented with PUFArich plant oils are fed, resulting in a shift in rumen microbial composition and a changed biohydrogenation pathway (Griinari and Bauman, 1999). In the present study, milk fat content (\%) decreased, but intake of $\mathrm{NDF}$ and starch, ruminal $\mathrm{pH}$, and milk fat yield $(\mathrm{g} / \mathrm{d})$ were unaffected with the LSO diet (Tables 2, 3, and 7). The increase of C18:1 trans-11 was greater compared with $\mathrm{C} 18: 1$ trans-10 as the $\mathrm{C} 18: 1$ trans- 11 to $\mathrm{C} 18: 1$ trans-10 ratio increased with the LSO diet (i.e., 4.6 \pm 0.19 for the CON diet and $6.0 \pm 0.46$ for the LSO diet; $P=0.009$ ). This indicates a change in the rumen biohydrogenation pathway, potentially the result of the increased rumen UFA load (Lock, 2010), causing changes in microbiota composition or activity, and thus changes in ruminal fermentation characteristics.

\section{Energy and Nitrogen Retention}

No diet $\times D G A T 1$ interaction was observed for the energy balance characteristics of the cows (Table 5). The ME intake (MEI) to GEI ratio was lower for the DGAT1 KK genotype $(66.8 \%)$ compared with the DGAT1 AA genotype $(67.9 \% ; P=0.023)$. To the best of our knowledge, the effects of DGAT1 on energy balance measured in CRC have not been quantified previously. The energy output in milk was unaffected by DGAT1 in the present study, which is in agreement with Bovenhuis et al. (2015) who only observed a difference in milk energy output for the DGAT1 AK genotype compared with DGAT1 AA and KK genotypes in parity 1. Bovenhuis et al. (2015) suggested that, in view of the absence of differences in energy output in milk, no large differences in energy balance between cows with different DGAT1 alleles would be expected. In the present study, total energy retention was unaffected by DGAT1 (Table 5), supporting the hypothesis of Bovenhuis et al. (2015). This is in agreement with Banos et al. (2008), who reported only a small positive effect of the DGAT1 K allele on cumulative effective energy balance estimated based on live weight and BCS.

The LSO diet resulted in a decreased energy loss in the form of $\mathrm{CH}_{4}(P=0.022$; Table 5$)$ and an increased MEI to GEI ratio $(P=0.006$; Table 5$)$. The decreasing effect of linseed oil on energy loss in the form of $\mathrm{CH}_{4}$, together with the tendency of reduced GE digestibility, may explain the difference in MEI to GEI ratio, because the GEI was unaffected by feeding linseed oil (Table 5).

The mean $\mathrm{N}$ balance was not affected by diet, DGAT1, and diet $\times D G A T 1$ interaction (Table 5). Milk N efficiency tended $(P=0.076)$ to be higher for the DGAT1 AA genotype (26.6\%) compared with the DGAT1 KK genotype $(25.5 \%)$. A few studies have reported the effect of dietary linseed oil on $\mathrm{N}$ balance and were reviewed by Hristov and Jouany (2005). These authors indicated that the effects of fat supplementation on the $\mathrm{N}$ balance of cattle are inconsistent in the literature. In the present study, the LSO diet reduced $\mathrm{N}$ excretion in manure $(P=0.010$; Table 5$)$, which is similar to Benchaar et al. (2015) and might be the result of the tendency observed for a lower $\mathrm{N}$ intake of cows fed the LSO diet. The LSO diet resulted in a greater efficiency 
LINSEED OIL, DGAT1, AND METHANE EMISSION

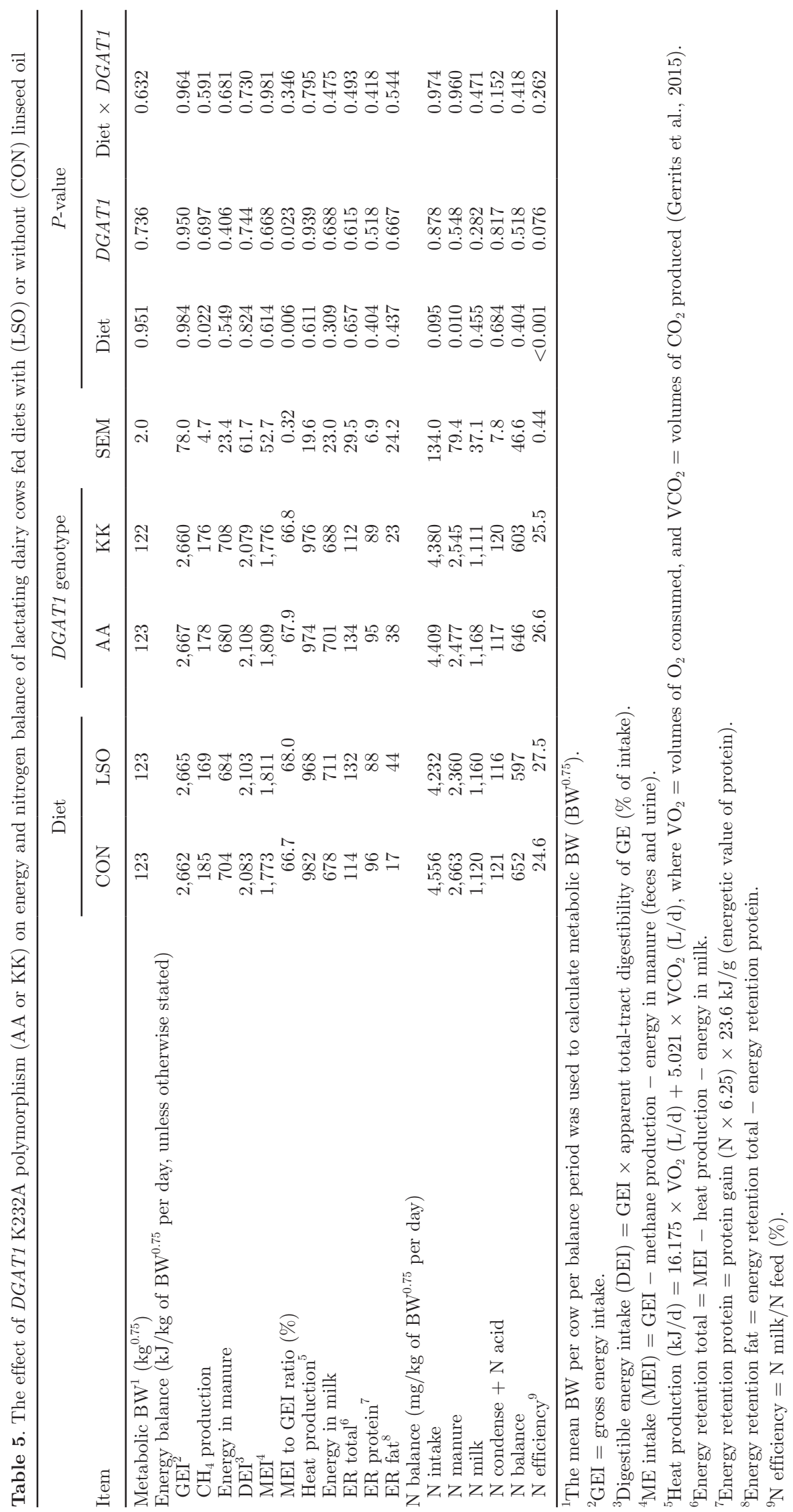


Table 6. The effect of DGAT1 K232A polymorphism (AA or KK) on gaseous consumption and production of lactating dairy cows fed diets with (LSO) or without (CON) linseed oil

\begin{tabular}{|c|c|c|c|c|c|c|c|c|}
\hline \multirow[b]{2}{*}{ Item } & \multicolumn{2}{|c|}{ Diet } & \multicolumn{2}{|c|}{$D G A T 1$ genotype } & \multirow[b]{2}{*}{ SEM } & \multicolumn{3}{|c|}{$P$-value } \\
\hline & $\mathrm{CON}$ & LSO & AA & KK & & Diet & $D G A T 1$ & Diet $\times D G A T 1$ \\
\hline $\mathrm{CO}_{2}$ production $(\mathrm{g} / \mathrm{d})$ & 12,351 & 12,001 & 12,184 & 12,168 & 379.2 & 0.517 & 0.975 & 0.997 \\
\hline Respiratory quotient & 1.12 & 1.10 & 1.10 & 1.11 & 0.005 & $<0.001$ & 0.178 & 0.580 \\
\hline \multicolumn{9}{|l|}{$\mathrm{H}_{2}$} \\
\hline $\mathrm{g} / \mathrm{d}$ & 1.79 & 1.65 & 1.71 & 1.73 & 0.097 & 0.310 & 0.906 & 0.196 \\
\hline \multicolumn{9}{|l|}{$\mathrm{CH}_{4}$} \\
\hline $\mathrm{g} / \mathrm{d}$ & 409 & 375 & 396 & 388 & 13.7 & 0.085 & 0.658 & 0.863 \\
\hline $\mathrm{g} / \mathrm{kg}$ of $\mathrm{DMI}$ & 22.9 & 21.5 & 22.3 & 22.1 & 0.32 & 0.006 & 0.688 & 0.572 \\
\hline $\mathrm{g} / \mathrm{kg}$ of $\mathrm{FPCM}^{1}$ & 15.5 & 13.8 & 14.7 & 14.6 & 0.35 & 0.002 & 0.925 & 0.430 \\
\hline$\%$ of $\mathrm{GEI}^{2}$ & 6.96 & 6.38 & 6.70 & 6.64 & 0.096 & $<0.001$ & 0.680 & 0.552 \\
\hline $\mathrm{CH}_{4}$ to $\mathrm{CO}_{2}$ ratio $^{3}$ & 0.033 & 0.031 & 0.032 & 0.032 & 0.0004 & 0.001 & 0.248 & 0.552 \\
\hline $\mathrm{H}_{2}$ to $\mathrm{CH}_{4}$ ratio ${ }^{4}$ & 0.0045 & 0.0045 & 0.0044 & 0.0046 & 0.00028 & 0.926 & 0.660 & 0.352 \\
\hline
\end{tabular}

${ }^{1}$ Fat- and protein-corrected milk $=(0.337+0.116 \times$ fat $\%+0.06 \times$ protein $\%) \times$ milk yield $(\mathrm{kg} / \mathrm{d})$.

${ }^{2}$ Gross energy intake.

${ }^{3}$ Ratio between $\mathrm{CH}_{4}(\mathrm{~g} / \mathrm{d})$ and $\mathrm{CO}_{2}(\mathrm{~g} / \mathrm{d})$.

${ }^{4}$ Ratio between $\mathrm{H}_{2}(\mathrm{~g} / \mathrm{d})$ and $\mathrm{CH}_{4}(\mathrm{~g} / \mathrm{d})$.

of dietary $\mathrm{N}$ utilization for milk $\mathrm{N}$ production $(P<$ 0.001). This is in contrast with Benchaar et al. (2015), who observed no effect of linseed oil supplementation on $\mathrm{N}$ efficiency.

\section{Gas Exchange}

No diet $\times D G A T 1$ interaction was found for $\mathrm{O}_{2}$ consumption and $\mathrm{CO}_{2}, \mathrm{CH}_{4}$, and $\mathrm{H}_{2}$ production, and gaseous ratios (Table 6). None of the gas exchange characteristics were affected by DGAT1. The results indicate that DGAT1 does not affect $\mathrm{CH}_{4}$ emission of dairy cows nor the response in $\mathrm{CH}_{4}$ emission of dairy cows to dietary linseed oil. As mentioned before, S. van Engelen (Wageningen University \& Research; unpublished data) performed a GWAS to determine regions of the bovine genome that are associated with predicted $\mathrm{CH}_{4}$ yield (g/ $\mathrm{kg}$ of DMI) using the equations published by Dijkstra et al. (2011) and van Engelen et al. (2015). The association with DGAT1 was significant in the GWAS for predicted $\mathrm{CH}_{4}$ yield, suggesting that the $\mathrm{K}$ allele is associated with higher predicted $\mathrm{CH}_{4}$ yield. The results of the present study suggest that the proposed relation between DGAT1 and $\mathrm{CH}_{4}$ based on predicted $\mathrm{CH}_{4}$ yield using MFA is not in line with actual observations on $\mathrm{CH}_{4}$ emission. Presumably, the relationship observed by S. van Engelen (Wageningen University \& Research; unpublished data) is due to the association between DGAT1 and the MFA that were used to predict $\mathrm{CH}_{4}$ yield. The $\mathrm{CH}_{4}$ prediction equations, used in the GWAS by S. van Engelen (Wageningen University \& Research; unpublished data), included several C18 UFA (both cis and trans isomers), which were affected by DGAT1 in the present study (Table 4) as well as in other studies (e.g., Schennink et al., 2007; Duchemin et al., 2013).

The LSO diet did not affect $\mathrm{H}_{2}$ production $(\mathrm{g} / \mathrm{d})$, yield $(\mathrm{g} / \mathrm{kg}$ of DMI), and intensity (g/ $\mathrm{kg}$ of FPCM), which is consistent with Veneman et al. (2015). Similarly, the unaffected $\mathrm{O}_{2}$ consumption and $\mathrm{CO}_{2}$ production upon the LSO diet in the present study is consistent with Livingstone et al. (2015). The LSO diet did not affect the $\mathrm{H}_{2}$ to $\mathrm{CH}_{4}$ ratio, but decreased the respiration quotient (RQ; $P<0.001), \mathrm{CH}_{4}$ emissions (i.e., $\mathrm{g} / \mathrm{kg}$ of DMI, $\mathrm{g} / \mathrm{kg}$ of FPCM, and \% of GEI; $P<0.006)$, and $\mathrm{CH}_{4}$ to $\mathrm{CO}_{2}$ ratio $(P=0.001$; Table 6$)$. The RQ is lower or equal to 1.0 when only substrate oxidation occurs (Gerrits et al., 2015). However, de novo FA synthesis and ruminal anaerobic fermentation of dietary carbohydrates can result in a RQ larger than 1.0 (Gerrits et al., 2015). The decreased RQ found for the LSO diet may result from the higher dietary fat intake and fat digestibility (Table 2) because fat is not fermented in the rumen (Beauchemin et al., 2008) and an increased absorption of FA reduces the need to synthesize FA from carbohydrates in the intermediary metabolism.

The decrease in $\mathrm{CH}_{4}$ emissions with the LSO diet in the present study is in line with previous studies (e.g., Martin et al., 2008; Benchaar et al., 2015). According to Grainger and Beauchemin (2011), a $10 \mathrm{~g} / \mathrm{kg}$ of DM increase in dietary fat should result in a decreased $\mathrm{CH}_{4}$ yield by $1 \mathrm{~g} / \mathrm{kg}$ of DMI in cattle. In the present study, the average increase in dietary fat content $(22 \mathrm{~g} / \mathrm{kg}$ of DM) was associated with a significant decrease of $1.4 \mathrm{~g} / \mathrm{kg}$ of $\mathrm{DMI}$ in $\mathrm{CH}_{4}$ yield. This is lower than that 
reported by Grainger and Beauchemin (2011) in their meta-analysis, but higher than some other studies (e.g., Veneman et al., 2015). Fat analyses of the feed residuals suggest that the cows in the present experiment were not selecting against the concentrate supplemented with linseed oil included in the TMR (results not shown; fat content in residual feed was not different from the fat content in TMR offered). Benchaar et al. (2015) suggested that the forage of the basal diets affected the extent of $\mathrm{CH}_{4}$ mitigation of linseed oil supplementation. For the red-clover-based diet, an increase in dietary fat content of $27 \mathrm{~g} / \mathrm{kg}$ of DM decreased $\mathrm{CH}_{4}$ yield with 1.7 $\mathrm{g} / \mathrm{kg}$ of DMI, whereas for the corn-silage-based diet, an increase in dietary fat content of $36 \mathrm{~g} / \mathrm{kg}$ of DM decreased $\mathrm{CH}_{4}$ yield with $4.0 \mathrm{~g} / \mathrm{kg}$ of DMI (Benchaar et al., 2015). The forages used in the present experiment (i.e., a mixture of grass silage and corn silage) may have influenced the extent of $\mathrm{CH}_{4}$ mitigation of dietary linseed oil. In addition, the 2 diets differed in $\mathrm{CP}$ content (194 and $184 \mathrm{~g} / \mathrm{kg}$ of DM for CON and LSO, respectively; Table 1), but the effect of dietary $\mathrm{CP}$ on $\mathrm{CH}_{4}$ emission is reported to be variable in the literature. Ellis et al. (2009) found a positive relationship between dietary $\mathrm{CP}$ content and $\mathrm{CH}_{4}$ emission of beef cattle, whereas Reynolds et al. (2010) did not observe differences in $\mathrm{CH}_{4}$ yield with different dietary $\mathrm{CP}$ contents. The $10 \mathrm{~g} / \mathrm{kg}$ of DM difference in dietary CP content between the 2 diets in the present study may not be expected to significantly affect $\mathrm{CH}_{4}$ emission, especially because the dietary $\mathrm{CP}$ content (i.e., higher than $180 \mathrm{~g} / \mathrm{kg}$ of DM; Table 1) was above calculated requirements for the dairy cows involved. Overall, it seems likely that the basal diet may have played an important role in the $\mathrm{CH}_{4}$ mitigation effect of dietary linseed oil in the present study.

\section{Ruminal Fermentation}

Three rumen fluid samples per cow within diet were collected: $1 \mathrm{~h}$ before and $4 \mathrm{~h}$ after morning feeding on $\mathrm{d}$ 12 , and $4 \mathrm{~h}$ after morning feeding on $\mathrm{d} 17$. None of the ruminal fermentation parameters significantly differed between d 12 and 17 at $4 \mathrm{~h}$ after morning feeding, with the exception of ruminal $\mathrm{pH}(P<0.001,6.56$ and 6.68 , respectively). To have a balanced design as well as the ability to distinguish between time and day effects, it was decided to use only the samples of $1 \mathrm{~h}$ before and $4 \mathrm{~h}$ after morning feeding of d 12 for ruminal fermentation data analysis.

Time of sampling (i.e., $1 \mathrm{~h}$ before feeding or $4 \mathrm{~h}$ after feeding) affected $\mathrm{pH}$, total VFA concentration, and VFA molar proportions $(P<0.001$; Table 7$)$, except for isovalerate. As expected, ruminal $\mathrm{pH}$ declined after feeding and total VFA concentration was higher $4 \mathrm{~h}$ after feeding compared with $1 \mathrm{~h}$ before feeding (data not shown). Total VFA concentration was unaffected by diet, DGAT1, and diet $\times D G A T 1$ interaction. The lack of an effect of the LSO diet is in agreement with Ueda et al. (2003), Doreau et al. (2009), and Benchaar et al. (2012), and all these results are consistent with the lack of effect of diet, DGAT1, and diet $\times D G A T 1$ interaction on ruminal $\mathrm{pH}$ in the present study.

In general, ruminal $\mathrm{pH}$ in the present study seems relatively high compared with the total VFA concentration (Table 7). According to the prediction equation derived by Dijkstra et al. (2012), $\mathrm{pH}$ should be around 6.2 with a VFA concentration of $100 \mathrm{mM}$. In the present study, however, $\mathrm{pH}$ was around 6.76 with a VFA concentration of approximately $93 \mathrm{~m} M$, probably as a result of collecting rumen fluid with the OST sampling technique. Duffield et al. (2004) and Wang et al. (2016)

Table 7. The effect of DGAT1 K232A polymorphism (AA or KK) on ruminal pH, total VFA concentration, and VFA molar proportions of lactating dairy cows fed diets with (LSO) or without (CON) linseed oil ${ }^{1}$

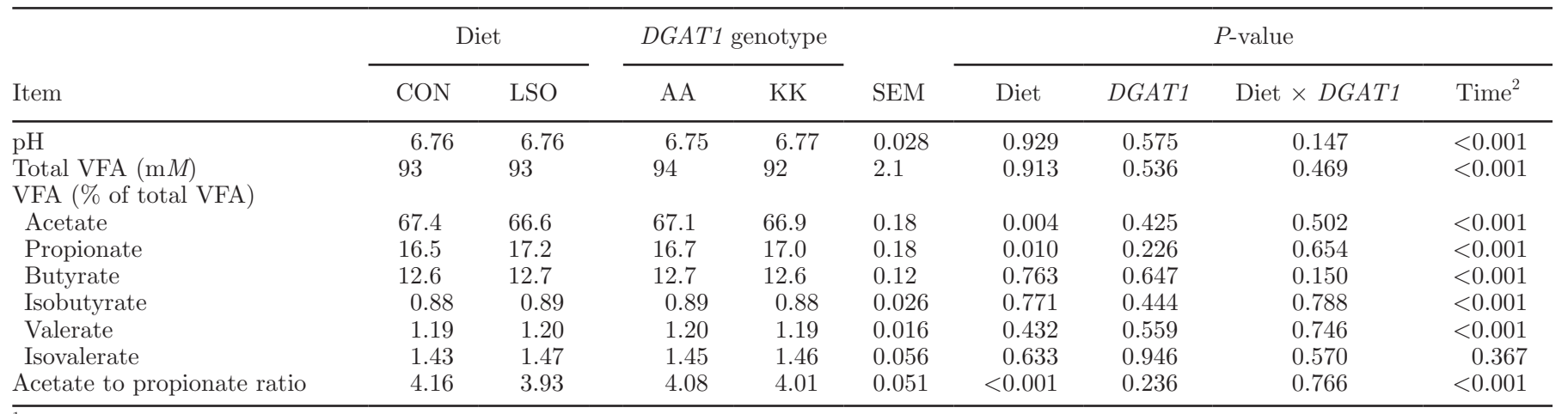

${ }^{1}$ Values shown represent the mean of values on $\mathrm{d} 12$ (i.e., $1 \mathrm{~h}$ before and $4 \mathrm{~h}$ after morning feeding).

${ }^{2}$ Time $=$ effect of time of sampling on $\mathrm{d} 12 ; 1 \mathrm{~h}$ before and $4 \mathrm{~h}$ after morning feeding. 
reported a higher ruminal $\mathrm{pH}$ when sampling rumen fluid using OST compared with rumen cannulation. Using the OST technique in the present study resulted in collection of rumen fluid from the ventral cranial part of the rumen or the reticulum. The $\mathrm{pH}$ within these regions of the reticulo-rumen is generally higher compared with other sites (e.g., Duffield et al., 2004; Li et al., 2009) as a result of rumination and the consequent entry of saliva.

The proportions of the individual VFA were unaffected by DGAT1 and diet $\times D G A T 1$ interaction (Table 7 ). Feeding the LSO diet resulted in an increased proportion of propionate $(P=0.010)$, whereas the proportion of acetate and the acetate to propionate ratio decreased compared with the CON $\operatorname{diet}(P=0.004$ and $P<0.001$, respectively). Several other studies have also reported a shift in VFA pattern toward proportionally more propionate and less acetate when a linseed oil containing diet was fed (e.g., Benchaar et al., 2012, 2015; Ivan et al., 2013; Martin et al., 2016), which is also consistent with the reduction of $\mathrm{CH}_{4}$ emission observed for the LSO diet (Table 6). This shift in fermentation toward propionate at the expense of acetate supports the key role of the redox state of NAD in rumen fermentation and $\mathrm{CH}_{4}$ production (van Lingen et al., 2017). As discussed before, dietary linseed oil may reduce fiber degradation in the rumen, whereas degradation of other carbohydrates (e.g., starch) remains unaffected (Doreau and Chilliard, 1997). This results in proportionally more propionate and less acetate. The apparent total-tract digestibility of NDF in the present study was unaffected by the LSO diet, but a decrease in rumen fiber digestion can be partially compensated for by digestion in the large intestine (Martin et al., 2008).

\section{Rumen Microbiota}

Bacterial and Archaeal Concentrations. The concentration of archaea and bacterial 16S rRNA genes in the rumen were unaffected by diet, DGAT1, and diet $\times$ DGAT1 interaction (Table 8). An absence of effect of linseed oil on archaeal concentrations is in agreement with Veneman et al. (2015) and Martin et al. (2016). Similar to Martin et al. (2016), despite the unaffected archaeal concentration, $\mathrm{CH}_{4}$ emission decreased with the LSO diet. The archaea to bacteria ratio decreased $(P=0.029$, Table 8$)$ with the LSO diet. This reduced ratio suggests that per unit substrate fermented by bacteria, a smaller archaeal concentration is present to form $\mathrm{CH}_{4}$, helping to explain the observed reduction in $\mathrm{CH}_{4}$ emission when feeding the LSO diet.

Numerous studies have repeatedly failed to find a correlation between $\mathrm{CH}_{4}$ emission and archaeal concentration (e.g., Morgavi et al., 2010). In the present study, archaeal concentration $\left(\log _{10} 16 \mathrm{~S}\right.$ copies $/ \mathrm{mL}$ of rumen fluid) was not related to $\mathrm{CH}_{4}$ production, but was related to $\mathrm{CH}_{4}$ yield $(\mathrm{r}=0.34, P=0.019)$, and tended to be related to $\mathrm{CH}_{4}$ intensity $(\mathrm{r}=0.28, P=$ 0.055 ) without considering effects of linseed oil and $D G A T 1$. Additionally, the archaea to bacteria ratio was not related to $\mathrm{CH}_{4}$ production, but was related to $\mathrm{CH}_{4}$ yield $(\mathrm{r}=0.43, P=0.002)$ and $\mathrm{CH}_{4}$ intensity $(\mathrm{r}=$ $0.48, P=0.001$ ) without considering effects of linseed oil and DGAT1. For both $\mathrm{CH}_{4}$ yield and $\mathrm{CH}_{4}$ intensity, the archaea to bacteria ratio provided the strongest correlation, which for $\mathrm{CH}_{4}$ yield is in agreement with Wallace et al. (2014).

Bacterial and Archaeal Composition. Bacteria (91.8 $\pm 2.1 \%$ of the obtained $16 \mathrm{~S}$ rRNA gene sequences) were represented by 1,077 different OTU, whereas the archaea $(7.9 \pm 2.0 \%$ of the $16 \mathrm{~S}$ rRNA sequences) were represented by 16 different OTU. In agreement with previous studies, the total number of bacterial OTU was much higher than archaeal ones (e.g., Kittelman et al., 2013; Veneman et al., 2015). The 1,093 OTU could be summarized to 89 different genus-level phylogenetic groupings ( 87 for bacteria and 2 for archaea). The rumen bacterial and archaeal community as a whole (i.e., PERMANOVA results) tended to be affected by diet $(P=0.081)$, but was not affected by $D G A T 1(P=$ $0.326)$ and diet $\times D G A T 1$ interaction $(P=0.365)$. We also individually analyzed the relative abundances of bacterial and archaeal genera to examine if these were affected by diet, DGAT1, and diet $\times D G A T 1$ interaction (Table 8). This was done because changes in taxa of low relative abundance can be masked when the total rumen microbiota is analyzed as a whole.

Methanobrevibacter was the most abundant archaeal genus, which is in line with other studies (e.g., Janssen and Kirs, 2008; Veneman et al., 2015). Both of the detected archaeal genera in this study were unaffected by diet, DGAT1, and diet $\times D G A T 1$ interaction, with the exception of Methanobrevibacter for which a tendency for a diet $\times D G A T 1$ interaction was observed. The lack of an effect of DGAT1 and of the interaction between $D G A T 1$ and dietary linseed oil on archaeal genera is in line with the lack of an effect of these factors on $\mathrm{CH}_{4}$ emissions in the present study (Table 6). The lack of an effect of linseed oil on both archaeal genera is in agreement with Veneman et al. (2015) and consistent with the unaffected archaeal concentrations in the present study. These results are also in agreement with Mosoni et al. (2008), who demonstrated that the long-chain FA of dietary linseed oil (such as linolenic acid) do not affect archaeal concentrations and relative abundances.

Prevotella was the most abundant bacterial genus in the present study, which was reported by others as well (e.g., Henderson et al., 2013; Veneman et al., 2015). 
Table 8. The effect of DGAT1 K232A polymorphism (AA or KK) on total concentrations and genus level relative abundances of archaea and bacteria in the rumen of lactating dairy cows fed diets with (LSO) or without (CON) linseed oil ${ }^{\mathbb{P}}$

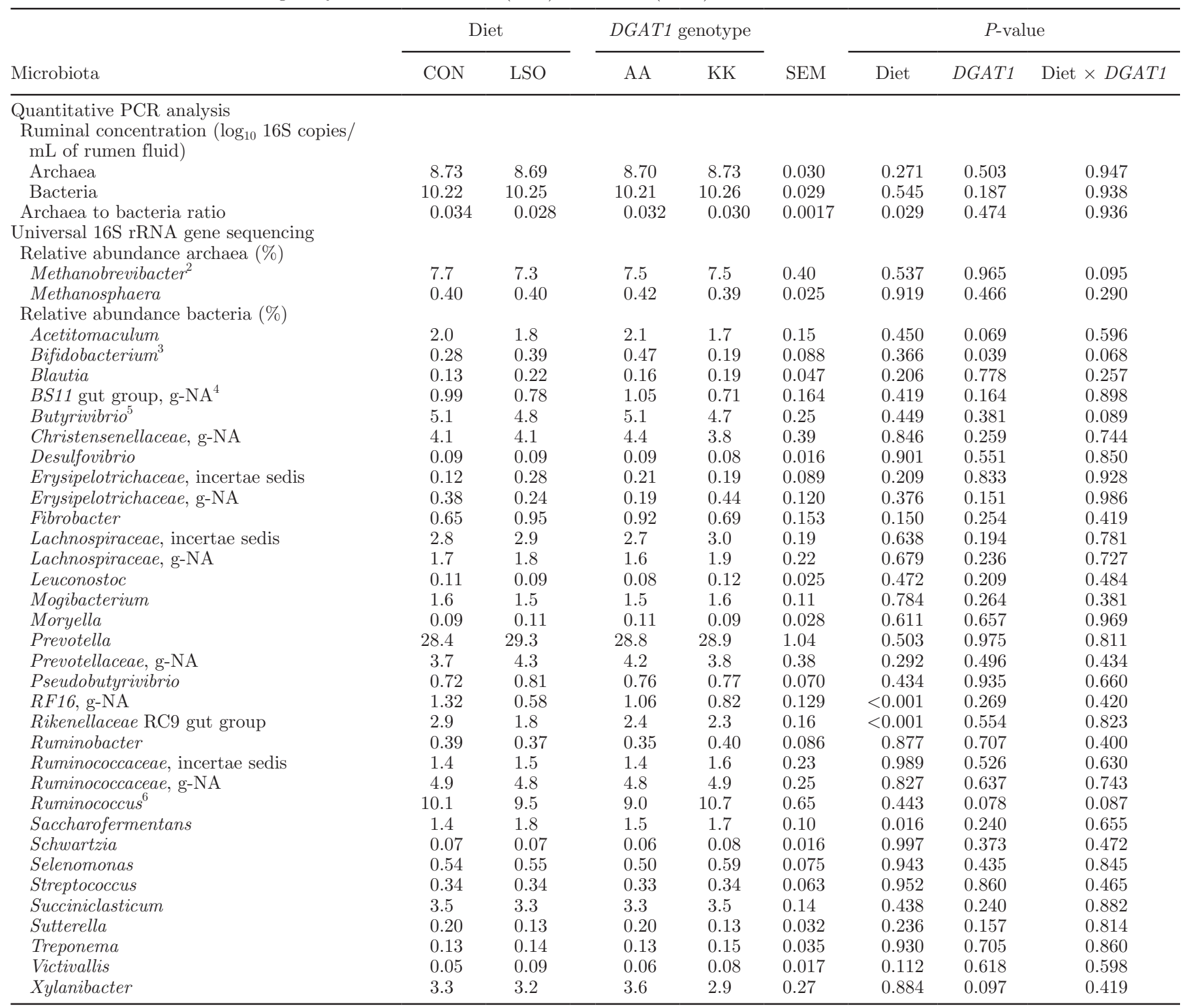

${ }^{1}$ Values shown represent $\mathrm{d} 17,4 \mathrm{~h}$ after morning feeding, and that of individual bacterial and archaeal genera that were (1) consistent in all animals and (2) were $>0.05 \%$ in terms of relative abundance.

${ }^{2}$ Diet $\times$ DGAT1 interaction; CON AA $=8.1$, LSO AA $=6.8$, CON KK $=7.2$, LSO KK $=7.8$.

${ }^{3}$ Diet $\times$ DGAT1 interaction; CON AA $=0.30$, LSO AA $=0.65$, CON KK $=0.25$, LSO KK $=0.14$.

${ }^{4}$ Taxonomic association of the genus-level phylogenetic grouping could not be assigned.

${ }^{5}$ Diet $\times$ DGAT1 interaction; $\mathrm{CON} \mathrm{AA}=5.5, \mathrm{LSO} \mathrm{AA}=4.6, \mathrm{CON} \mathrm{KK}=4.5, \mathrm{LSO} \mathrm{KK}=4.9$.

${ }^{6}$ Diet $\times$ DGAT1 interaction; CON AA $=10.1, \mathrm{LSO} \mathrm{AA}=7.8, \mathrm{CON} \mathrm{KK}=10.2, \mathrm{LSO} \mathrm{KK}=11.0$.

The relative abundance of Bifidobacterium $(P=0.039)$ was lower for the DGAT1 KK genotype compared with the DGAT1 AA genotype (Table 8). Bifidobacterium is a sugar fermenting bacteria (Trovatelli and Matteuzzi, 1976) producing acetate. However, intake of reducing sugars (Table 2) as well as the molar proportions of acetate (Table 7 ) was not affected by DGAT1.
With the LSO diet, Rikenellaceae RC9 gut group and a nonassigned genus (g-NA) within the RF16 decreased $(P<0.001$ for both), whereas Saccharofermentans increased ( $P=0.016$; Table 8$)$. There is no cultured representative of $R F 16, \mathrm{~g}-\mathrm{NA}$, and hence the lack of knowledge with respect to the physiology of this group makes it unclear why their relative abundance 
decreased with the LSO diet. The metabolic function and role of the Rikenellaceae RC9 gut group in the rumen microbiome remains to be defined, but Zened et al. (2013) already demonstrated that supplementation of sunflower oil decreased its relative abundance. Saccharofermentans is a sugar fermenting bacteria (Chen et al., 2010). The reducing sugar content and intake of the LSO diet was lower compared with the CON diet (Table 1,2), which is not consistent with the increased relative abundance of sugar fermenting bacteria.

The PUFA present in linseed oil are believed to have a toxic effect on cellulolytic bacteria (Nagaraja et al., 1997; Martin et al., 2010). This negative effect of linseed supplementation on cellulolytic bacteria has not been confirmed in vivo in dairy cows by Veneman et al. (2015). Additionally, in the present study, no effect was observed on cellulolytic genera (such as Fibrobacter, Butyrivibrio, and Ruminococcus, $P>0.150$, Table $8)$. This indicates that dietary linseed oil at the level used in the present study does not have a toxic effect on cellulolytic bacteria, and thus does not affect their relative abundance, and that this is therefore not the mode of action of dietary linseed oil to decrease $\mathrm{CH}_{4}$ production. The results of the present study, however, do not reject the potential toxic effect of dietary linseed oil on the metabolic activity of cellulolytic bacteria.

Overall, the results indicate that several rumen bacterial genera were affected by dietary linseed oil, which could be linked to changes in dietary composition, differences in ruminal fermentation characteristics, and gaseous exchange. Further, several rumen bacterial genera were affected by DGAT1, but could not be linked with ruminal fermentation characteristics and gaseous exchange because the latter 2 were not affected by DGAT1. As a consequence, the biological implications of their change appear to be limited. Despite some bacterial genera being affected by diet, DGAT1, and diet $\times D G A T 1$ interaction (i.e., the latter only tendencies), the bacterial and archaeal community as a whole was not significantly affected. This is perhaps because more than $75 \%$ of the bacterial genera analyzed were unaffected by diet, DGAT1, and diet $\times D G A T 1$ interaction, and because the quantities of the affected bacterial genera were relatively small, therefore representing only a minor part of the rumen microbiota.

\section{Implications}

We acknowledge that the results of this study could have been different if the cows would have been fed ad libitum. We restricted feed intake to ensure similar feed intake between treatments, thus avoiding confounding effects of DMI on $\mathrm{CH}_{4}$ production. Feed intake restriction ranged from 82 to $95 \%$ with an average of $92 \pm$
$0.7 \%$, with all cows being in positive energy balance and no difference in milk yield $(25.5 \pm 1.08$ when fed ad libitum and $25.3 \pm 1.16$ when feed intake was restricted). We, therefore, consider the overall effect of restricted feeding to be minimal. However, when considering the individual treatments, this may be different. The LSO receiving cow was in $67 \%$ of the cases the one with the lowest ad libitum feed intake within a block, and thus the CON receiving cow was in $67 \%$ of the cases relatively more restricted in her feed intake. In other words, when fed ad libitum, the LSO diet could have resulted in a lower feed intake relatively to the CON diet. For $D G A T 1$, we did not find an association between ad libitum feed intake and the DGAT1 KK or AA genotype.

Additionally, we acknowledge that the absence of effects of DGAT1 might be related to the number of animals used in the present study. Many genetic studies used hundreds to thousands of animals (e.g., Bovenhuis et al., 2016), whereas only 24 animals were used in the present study. It is known that DGAT1 has major effects on milk yield and composition (such as milk fat content and milk protein content). The present study was able to confirm the difference in milk composition between the DGAT1 KK and AA genotype, but for milk yield only a tendency was found. This shows that the number of animals in the present study might have been insufficient to find all known major effects of DGAT1. For marginal effects, such as $\mathrm{CH}_{4}$ production, which differed $8 \mathrm{~g} / \mathrm{d}$ between the DGAT1 AA and KK genotypes ( $2 \%$ relative difference), this study did not have sufficient power because of the relative small number of animals. Furthermore, no dairy cows with the heterozygous DGAT1 AK genotype were included in the present study. We assumed the AK genotype would be in between the homozygous DGAT1 AA and KK genotypes, because there is little evidence for dominance effects of DGAT1 (Bovenhuis et al., 2015). Whether this is also the case for other parameters, as measured in the current study, remains to be investigated.

Overall, the results of the present study suggest that DGAT1 does not affect enteric $\mathrm{CH}_{4}$ emission and production pathways, but that it does affect traits other than lactation characteristics, including metabolizability, $\mathrm{N}$ efficiency, and the relative abundance of Bifidobacterium. Additionally, linseed oil reduces $\mathrm{CH}_{4}$ emission independent of DGAT1 and affects the rumen microbiota and its fermentative activity.

\section{CONCLUSIONS}

Nutrient digestibility, $\mathrm{CH}_{4}$ and $\mathrm{H}_{2}$ emission, ruminal fermentation, rumen archaeal and bacterial concentrations, and the ruminal bacterial and archaeal com- 
munity as a whole were not affected by DGAT1. The major effects of $D G A T 1$ on milk fat and protein content were independent of dietary linseed oil. Also, DGAT1 affected other traits, including metabolizability, $\mathrm{N}$ efficiency, and the relative abundance of Bifidobacterium. Upon feeding linseed oil, $\mathrm{H}_{2}$ emissions did not change, whereas $\mathrm{CH}_{4}$ production $(\mathrm{g} / \mathrm{d}$ ) decreased with $8 \%$ (tendency only), $\mathrm{CH}_{4}$ yield ( $\mathrm{g} / \mathrm{kg}$ of DMI) decreased with $6 \%$, and $\mathrm{CH}_{4}$ intensity $(\mathrm{g} / \mathrm{kg}$ of FPCM) decreased with $11 \%$, independent of DGAT1. In line with this, an increase in ruminal propionate proportion and a decrease in acetate proportion as well as acetate to propionate ratio was observed, and the archaea to bacteria ratio also decreased for the LSO diet. Linseed oil tended to affect the ruminal bacterial composition and affected the relative abundance of several bacterial genera.

\section{ACKNOWLEDGMENTS}

Lydia Kroon and Priscilla Gerritsen (students of Wageningen University \& Research, the Netherlands) and the staff of the experimental facilities "Carus" (Wageningen, the Netherlands) are gratefully acknowledged for their assistance during the implementation of the experiment, as are the laboratory staff of the Animal Nutrition Group (Wageningen, the Netherlands). Bartholomeus van den Bogert and Jueeli D. Vaidya (both of Laboratory of Microbiology, Wageningen, the Netherlands) are acknowledged for their extensive help during rumen fluid collection, Edoardo Saccenti (Laboratory of Microbiology, Wageningen, the Netherlands) for running the PERMANOVA analysis, and Caroline Plugge (Laboratory of Microbiology, Wageningen, the Netherlands) for her support and guidance regarding the microbial data. This study was part of the TI Food and Nutrition program "Reduced methane emissions from dairy cows: Towards sustainable dairy cattle production by increased understanding of genetic variation and rumen functioning." Financial support was obtained from the Centraal Bureau Levensmiddelenhandel (CBL; Leidschendam, the Netherlands), Cooperative Cattle Improvement Organization CRV (Arnhem, the Netherlands), Federatie Nederlandse Levensmiddelen Industrie (FNLI; The Hague, the Netherlands), Lely Industries NV (Maassluis, the Netherlands), Ministry of Economic Affairs (The Hague, the Netherlands), Qlip BV (Zutphen, the Netherlands), Wageningen University \& Research (Wageningen, the Netherlands), and ZuivelNL (Zoetermeer, the Netherlands).

\section{REFERENCES}

Abrahamse, P. A., J. Dijkstra, B. Vlaeminck, and S. Tamminga. 2008. Frequent allocation of rotationally grazed dairy cows changes graz- ing behavior and improves productivity. J. Dairy Sci. 91:20332045.

Anderson, M. J. 2001. A new method for non-parametric multivariate analysis of variance. Austral Ecol. 26:32-46.

Banos, G., J. A. Woolliams, B. W. Woodward, A. B. Forbes, and M. P. Coffey. 2008. Impact of single nucleotide polymorphisms in leptin, leptin receptor, growth hormone receptor, and diacylglycerol acyltransferase (DGAT1) gene loci on milk production, feed, and body energy traits of UK dairy cows. J. Dairy Sci. 91:3190-3200.

Bauman, D. E., and J. M. Griinari. 2003. Nutritional regulation of milk fat synthesis. Annu. Rev. Nutr. 23:203-227.

Bauman, D. E., K. J. Harvatine, and A. L. Lock. 2011. Nutrigenomics, rumen-derived bioactive fatty acids, and the regulation of milk fat synthesis. Annu. Rev. Nutr. 31:299-319.

Beauchemin, K., T. A. McAllister, and S. McGinn. 2009. Dietary mitigation of enteric methane from cattle. CAB Rev. Perspect. Agric. Vet. Sci. Nutr. Nat. Resour. 35:1-18.

Beauchemin, K. A., M. Kreuzer, F. O'Mara, and T. A. McAllister 2008. Nutritional management for enteric methane abatement: A review. Aust. J. Exp. Agric. 48:21-27.

Benchaar, C., F. Hassanat, R. Martineau, and R. Gervais. 2015. Linseed oil supplementation to dairy cows fed diets based on red clover silage or corn silage: Effects on methane production, rumen fermentation, nutrient digestibility, $\mathrm{N}$ balance, and milk production. J. Dairy Sci. 98:7993-8008.

Benchaar, C., G. A. Romero-Pérez, P. Y. Chouinard, F. Hassanat, M. Eugene, H. V. Petit, and C. Côrtes. 2012. Supplementation of increasing amounts of linseed oil to dairy cows fed total mixed rations: Effects on digestion, ruminal fermentation characteristics, protozoal populations, and milk fatty acids composition. J. Dairy Sci. 95:4578-4590.

Bernard, L., C. Leroux, and Y. Chilliard. 2008. Expression and nutritional regulation of lipogenic genes in the ruminant lactating mammary gland. Adv. Exp. Med. Biol. 606:67-108.

Bovenhuis, H., M. H. P. W. Visker, N. A. Poulsen, J. Sehested, H. J. F. van Valenberg, J. A. M. van Arendonk, L. B. Larsen, and A. J. Buitenhuis. 2016. Effect of the diacylglycerol o-acyltransferase 1 (DGAT1) K232A polymorphism on fatty acid, protein, and mineral composition of dairy cattle milk. J. Dairy Sci. 99:3113-3123.

Bovenhuis, H., M. H. P. W. Visker, H. J. F. van Valenberg, A. J. Buitenhuis, and J. A. M. van Arendonk. 2015. Effects of the DGAT1 polymorphism on test-day milk production traits throughout lactation. J. Dairy Sci. 98:6572-6582.

Byers, F. M., and G. T. Schelling. 1988. Lipids in ruminant nutrition. Page 298 in The Ruminant Animal Digestive Physiology and Nutrition. D. C. Church, ed. Prentice-Hall, Englewood Cliffs, NJ.

Caporaso, J. G., C. L. Lauber, W. A. Walters, D. Berg-Lyons, J. Huntley, N. Fierer, S. M. Owens, J. Betley, L. Fraser, M. Bauer, N. Gormley, J. A. Gilbert, G. Smith, and R. Knight. 2012. Ultrahigh-throughput microbial community analysis on the Illumina HiSeq and MiSeq platforms. ISME J. 6:1621-1624.

Chen, S., L. Niu, and Y. Zhang. 2010. Saccharofermentans acetigenes gen. nov., sp. nov., an anaerobic bacterium isolated from sludge treating brewery wastewater. Int. J. Syst. Evol. Microbiol. 60:2735-2738.

Chilliard, Y., C. Martin, J. Roual, and M. Doreau. 2009. Milk fatty acids in dairy cows fed whole crude linseed, extruded linseed, or linseed oil, and their relationship with methane output. J. Dairy Sci. 92:5199-5211.

DeVita, R. J., and S. Pinto. 2013. Current status of the research and development of diacylglycerol o-acyltransferase 1 (DGAT1) inhibitors. J. Med. Chem. 56:9820-9825.

Dijkstra, J., J. L. Ellis, E. Kebreab, A. B. Strathe, S. López, J. France, and A. Bannink. 2012. Ruminal pH regulation and nutritional consequences of low pH. Anim. Feed Sci. Technol. 172:22-33.

Dijkstra, J., S. M. van Zijderveld, J. A. Apajalahti, A. Bannink, W. J. J. Gerrits, J. R. Newbold, H. B. Perdok, and H. Berends. 2011. Relationships between methane production and milk fatty acid profiles in dairy cattle. Anim. Feed Sci. Technol. 166-167:590-595.

Doreau, M., E. Aurousseau, and C. Martin. 2009. Effects of linseed lipids fed as rolled seeds, extruded seeds or oil on organic matter 
and crude protein digestion in cows. Anim. Feed Sci. Technol. 150:187-196.

Doreau, M., and Y. Chilliard. 1997. Digestion and metabolism of dietary fat in farm animals. Br. J. Nutr. 78:S15-S35.

Duchemin, S., H. Bovenhuis, W. M. Stoop, A. C. Bouwman, J. A. M van Arendonk, and M. H. P. W. Visker. 2013. Genetic correlation between composition of bovine milk fat in winter and summer, and DGAT1 and SCD1 by season interactions. J. Dairy Sci. 96:592-604.

Duffield, T., J. C. Plaizier, A. Fairfield, R. Bagg, G. Vessie, P. Dick, J. Wilson, J. Aramini, and B. McBride. 2004. Comparison of techniques for measurement of rumen $\mathrm{pH}$ in lactating dairy cows. J. Dairy Sci. 87:59-66.

Ellis, J. L., E. Kebreab, N. E. Odongo, K. Beauchemin, S. McGinn, J. D. Nkrumah, S. S. Moore, R. Christopherson, G. K. Murdoch, B. W. McBride, E. K. Okine, and J. France. 2009. Modelling methane production from beef cattle using linear and nonlinear approaches. J. Anim. Sci. 87:1334-1345.

Ferlay, A., M. Doreau, C. Martin, and Y. Chilliard. 2013. Effects of incremental amounts of extruded linseed on the milk fatty acid composition of dairy cows receiving hay or corn silage. J. Dairy Sci. 96:6577-6595.

Gerrits, W. J. J., J. J. G. C. van den Borne, and E. Labussière. 2015. Deriving heat production from gaseous exchange: Validity of the approach. Pages 19-34 in Indirect Calorimetry. Techniques, Computations and Applications. W. J. J. Gerrits and E. Labussière, ed. Wageningen Academic Publishers, Wageningen, the Netherlands.

Grainger, C., and K. A. Beauchemin. 2011. Can enteric methane emissions from ruminants be lowered without lowering their production? Anim. Feed Sci. Technol. 166-167:308-320.

Griinari, J. M., and D. E. Bauman. 1999. Biosynthesis of conjugated linoleic acid and its incorporation into meat and milk in ruminants. Pages 180-200 in Advances in Conjugated Linoleic Acid Research. M. P. Yurawecz, M. M. Mossoba, J. K. G. Kramer, M. W. Pariza, and G. J. Nelson, ed. AOCS Press, Champaign, IL.

Griinari, J. M., B. A. Corl, S. H. Lacy, P. Y. Chouinard, K. V. V. Nurmela, and D. E. Bauman. 2000. Conjugated linoleic acid is synthesized endogenously in lactating dairy cows by Delta-9 desaturase. J. Nutr. 130:2285-2291.

Heetkamp, M. J. W., S. J. J. Alferink, T. Zandstra, P. Hendriks, H van den Brand, and W. J. J. Gerrits. 2015. Design of climate respiration chambers, adjustable to the metabolic mass of subjects. Pages 35-56 in Indirect Calorimetry. Techniques, Computations and Applications. W. J. J. Gerrits and E. Labussière, ed. Wageningen Academic Publishers, Wageningen, the Netherlands.

Henderson, G., F. Cox, S. Kittelmann, V. H. Miri, M. Zethof, S. J. Noel, G. C. Waghorn, and P. H. Janssen. 2013. Effect of DNA extraction methods and sampling techniques on the apparent structure of cow and sheep rumen microbial communities. PLoS One 8:e74787.

Hristov, A. N., and J. P. Jouany. 2005. Factors affecting the efficiency of nitrogen utilization in the rumen. Pages 117-166 in Nitrogen and Phosphorus Nutrition of Cattle: Reducing the Environmental Impact of Cattle Operations. E. Pfeffer and A. N. Hristov, ed. CAB International, Cambridge, MA.

Hristov, A. N., J. Oh, J. L. Firkins, J. Dijkstra, E. Kebreab, G. Waghorn, H. P. S. Makkar, A. T. Adesogan, W. Yang, C. Lee, P. J Gerber, B. Henderson, and J. M. Tricarico. 2013. Special topics - Mitigation of methane and nitrous oxide emissions from animal operations: I. A review of enteric methane mitigation options. J. Anim. Sci. 91:5045-5069.

International Organization for Standardization. 1998. ISO 9831:1998. Animal feedstuffs, animal products, and faeces or urine-Determination of gross caloric values-Bomb calorimeter method. International Organization for Standardization, Geneva, Switzerland.

International Organization for Standardization. 1999. ISO 9622:1999. Whole milk-Determination of milkfat, protein and lactose content - guidance on the operation of mid-infrared instruments. International Organization for Standardization, Geneva, Switzerland.
International Organization for Standardization. 2004a. ISO 1735:2004. Animal Feeding Stuffs. Determination of Fat Content. Geneva: International Organization for Standardization.

International Organization for Standardization. 2004b. ISO 14637:2004. Milk-Determination of urea content - Enzymatic method using difference in $\mathrm{pH}$ (reference method). International Organization for Standardization, Geneva, Switzerland.

International Organization for Standardization. 2005. ISO 5983:2005. Animal feeding stuffs. Determination of nitrogen content and calculation of crude protein content-Part 1: Kjeldahl method. International Standards Organization, Geneva, Switzerland.

Ivan, M., H. V. Petit, J. Chiquette, and A. D. G. Wright. 2013. Rumen fermentation and microbial population in lactating dairy cows receiving diets containing oilseeds rich in $\mathrm{C} 18$ fatty acids. Br. J. Nutr. 109:1211-1218.

Janssen, P. H., and M. Kirs. 2008. Structure of the archaeal community of the rumen. Appl. Environ. Microbiol. 74:3619-3625.

Jones, D. L. 2015. Fathom Toolbox for Matlab: Software for Multivariate Ecological and Oceanographic Data Analysis. St. Petersburg, FL: College of Marine Science, University of South Florida. Accessed Nov. 28, 2016. http://www.marine.usf.edu/user/djones/.

Khan, N. A., J. W. Cone, and W. H. Hendriks. 2009. Stability of fatty acids in grass and maize silages after exposure to air during the feed out period. Anim. Feed Sci. Technol. 154:183-192.

Kittelman, S., H. Seedorf, W. A. Walters, J. C. Clemente, R. Knight, J. I. Gordon, and P. H. Janssen. 2013. Simultaneous amplicon sequence to explore co-occurance patterns of bacterial, archaeal and eukaryotic microorganisms in rumen microbial communities. PLoS One 8:e47879.

Klop, G., B. Hatew, A. Bannink, and J. Dijkstra. 2016. Feeding nitrate and docosahexaenoic acid affects enteric methane production and milk fatty acid composition in lactating dairy cows. J. Dairy Sci. 99:1161-1172.

Klop, G., S. van Laar-van Schuppen, W. F. Pellikaan, W. H. Hendriks, A. Bannink, and J. Dijkstra. 2017. Changes in in vitro gas and methane production from rumen fluid from dairy cows during adaptation to feed additives in vivo. Animal 11:591-599.

Li, M., G. B. Penner, E. Hernandez-Sanabria, M. Oba, and L. L. Guan. 2009. Effects of sampling location and time, and host animal on assessment of bacterial diversity and fermentation parameters in the bovine rumen. J. Appl. Microbiol. 107:1924-1934.

Livingstone, K. M., D. J. Humphries, P. Kirton, K. E. Kliem, D. I. Givens, and C. K. Reynolds. 2015. Effects of forage type and extruded linseed supplementation on methane production and milk fatty acids composition of lactating dairy cows. J. Dairy Sci. 98:4000-4011

Lock, A. 2010. Update on dietary and management effects on milk fat. Pages 15-26 in Proc. Tri-State Dairy Nutr. Conf., Fort Wayne, IN The Ohio State University, Columbus.

Lu, J., S. Boeren, T. van Hooijdonk, J. Vervoort, and K. A. Hettinga. 2015. Effect of the DGAT1 K232A genotype of dairy cows on the milk metabolome and proteome. J. Dairy Sci. 98:3460-3469.

Martin, C., A. Ferlay, P. Mosoni, Y. Rochette, Y. Chilliard, and M. Doreau. 2016. Increasing linseed supply in dairy cow diets on hay and corn silage: Effect on enteric methane emission, rumen microbial fermentation, and digestion. J. Dairy Sci. 99:3445-3456.

Martin, C., D. P. Morgavi, and M. Doreau. 2010. Methane mitigation in ruminants: From microbe to the farm scale. Animal 4:351-365.

Martin, C., J. Roual, J. P. Jouany, M. Doreau, and Y. Chilliard. 2008 Methane output and diet digestibility in response to feeding dairy cows crude linseed, extruded linseed, or linseed oil. J. Anim. Sci. $86: 2642-2650$

Morgavi, D. P., E. Forano, C. Martin, and C. J. Newbold. 2010 Microbial ecosystem and methanogenesis in ruminants. Animal 4:1024-1036.

Mosoni, P., Y. Rochette, M. Doreau, D. P. Morgavi, E. Forano, A. Ferlay, Y. Chilliard, and C. Martin. 2008. Effect of increasing levels of extruded linseed in the diet of dairy cows on the number of protozoa, cellulolytic bacteria and methanogenic archaea. Page 84 in Proc. of 6th INRA-RRI Symposium on the Gut Microbiome, 18-20 June 2008, Clermont-Ferrand, France. 
Muise, E. S., Y. Zhu, A. Verras, B. V. Karanam, J. Gorski, D. Weingarth, H. V. Lin, J. Hwa, J. R. Thompson, G. Hu, J. Liu, S. He, R. J. DeVita, D. M. Shen, and S. Pinto. 2014. Identification and characterization of sebaceous gland atrophy-sparing DGAT1 inhibitors. PLoS One 9:e88908.

Nagaraja, T. G., C. J. Newbold, C. J. Van Nevel, and D. I. Demeyer. 1997. Manipulation of ruminal fermentation. Pages 523-632 in The Rumen Microbial Ecosystem. P. N. Hobson and C. S. Stewart, ed. Blackie Academic \& Professional, London, UK.

Näslund, J., W. F. Fikse, G. R. Pielberg, and A. Lunden. 2008. Frequency and effect of the bovine acyl-CoA:diacylglycerol dcyltransferase 1 (DGAT1) K232A polymorphism in Swedish dairy cattle. J. Dairy Sci. 91:2127-2134.

Pellikaan, W. F., M. W. A. Verstegen, S. Tamminga, J. Dijkstra, and W. H. Hendriks. 2013. $\delta 13 \mathrm{C}$ as a marker to study digesta passage kinetics in ruminants: A combined in vivo and in vitro study. Animal 7:754-767.

Quast, C., E. Pruesse, P. Yilmaz, J. Gerken, T. Schweer, P. Yarza, J. Peplies, and F. O. Glockner. 2013. The SILVA ribosomal RNA gene database project: Improved data processing and web-based tools. Nucleic Acids Res. 41:590-596.

Ramiro-Garcia, J., G. D. A. Hermes, C. Giatsis, D. Sipkema, E. G. Zoetendal, P. J. Schaap, and H. Smidt. 2016. NG-Tax, a highly accurate and validated pipeline for analysis of $16 \mathrm{~S}$ rRNA amplicons from complex biomes. F1000 Res. 5:1791.

Reynolds, C. K., L. A. Crompton, J. A. N. Mills, D. J. Humphries, P. Kirton, A. E. Relling, T. H. Misselbrook, D. R. Chadwick, and D. I. Givens. 2010. Effects of diet protein level and forage source on energy and nitrogen balance and methane and nitrogen excretion in lactating dairy cows. Pages 463-464 in Proc. 3rd EAAP International Symposium on Energy and Protein Metabolism and Nutrition. G. M. Crovetto, ed. Wageningen Academic Publishers, Parma, Italy.

Saliba, L., R. Gervais, Y. Lebeuf, and P. Y. Chouinard. 2014. Effect of feeding linseed oil in diets differing in forage to concentrate ratio: 1. Production performance and milk fat content of biohydrogenation intermediates of $\alpha$-linolenic acid. J. Dairy Res. 81:82-90.

Schennink, A., J. M. L. Heck, H. Bovenhuis, M. H. P. W. Visker, H. J. F. Van Valenberg, and J. A. M. Van Arendonk. 2008. Milk fatty acid unsaturation: Genetic parameters and effects of stearoyl-CoA desaturase (SCD1) and acyl CoA: diacylglycerol acyltransferase (DGAT1). J. Dairy Sci. 91:2135-2143.

Schennink, A., W. M. Stoop, M. H. P. W. Visker, J. M. L. Heck, H. Bovenhuis, J. J. van der Poel, H. J. F. van Valenberg, and J. A. M. van Arendonk. 2007. DGAT1 underlies large genetic variation in milk-fat composition of dairy cows. Anim. Genet. 38:467-473.

Schroeder, G. F., G. A. Gagliostro, F. Bargo, J. E. Delahoy, and L. D. Muller. 2004. Effects of fat supplementation on milk production and composition by dairy cows on pasture: A review. Livest. Prod. Sci. 86:1-18

Shen, J. S., A. Chai, L. J. Song, J. X. Liu, and Y. M. Wu. 2012. Insertion depth of oral stomach tubes may affect the fermentation parameters of ruminal fluid collected in dairy cows. J. Dairy Sci. 95:5978-5984.

Spek, J. W., J. Dijkstra, G. van Duinkerken, and A. Bannink. 2013. A review of factors influencing milk urea concentration and its relationship with urinary urea excretion in lactating dairy cattle. J. Agric. Sci. 151:407-423.

Tian, L., J. Scholte, K. Borewicz, B. van den Bogert, H. Smidt, A. J. Scheurink, H. Gruppen, and H. A. Schols. 2016. Effects of pectin supplementation on the fermentation patterns of different structural carbohydrates in rats. Mol. Nutr. Food Res. 60:2256-2266.

Trovatelli, L. D., and D. Matteuzzi. 1976. Presence of Bifidobacteria in the rumen of calves fed different rations. Appl. Environ. Microbiol. 32:470-473.

Ueda, K., A. Ferlay, J. Chabrot, J. J. Loor, Y. Chilliard, and M. Doreau. 2003. Effect of linseed oil supplementation on ruminal digestion in dairy cows fed diets with different forage:concentrate ratios. J. Dairy Sci. 86:3999-4007.

Van Arendonk, J. A. M., J. M. L. Heck, A. Schennink, and M. H. P. W. Visker, inventors. 2009. Method for selection of bovines producing milk with improved fatty acid composition. Wageningen University, Holland Genetics B.V., and Vereniging De Nederlandse Zuivel Organisatie. NL Pat. No. WO2008NL50085.

Van Duinkerken, G., M. C. Blok, A. Bannink, J. W. Cone, J. Dijkstra, A. M. van Vuuren, and S. Tamminga. 2011. Update of the Dutch protein evaluation system for ruminants: The $\mathrm{DVE} / \mathrm{OEB}_{2010}$ system. J. Agric. Sci. 149:351-367.

van Engelen, S., H. Bovenhuis, J. Dijkstra, J. A. M. van Arendonk, and M. H. P. W. Visker. 2015. Short communication: Genetic study of methane production predicted from milk fat composition in dairy cows. J. Dairy Sci. 98:8223-8226.

Van Es, A. J. H. 1978. Feed evaluation for ruminants. I. The systems in use from May 1977-onwards in the Netherlands. Livest. Prod. Sci. 5:331-345.

van Gastelen, S., E. C. Antunes-Fernandes, K. A. Hettinga, G. Klop, S. J. J. Alferink, W. H. Hendriks, and J. Dijkstra. 2015. Enteric methane production, rumen volatile fatty acid concentrations, and milk fatty acid composition in lactating Holstein-Friesian cows fed grass silage- or corn silage-based diets. J. Dairy Sci. 98:1915-1927.

van Gastelen, S., and J. Dijkstra. 2016. Prediction of methane emission from lactating dairy cows using milk fatty acids and midinfrared spectroscopy. J. Sci. Food Agric. 96:3963-3968.

van Lingen, H. J., J. E. Edwards, J. D. Vaidya, S. van Gastelen, E. Saccenti, B. van den Bogert, A. Bannink, H. Smidt, C. M. Plugge, and J. Dijkstra. 2017. Diurnal dynamics of gaseous and dissolved metabolites and microbiota composition in the bovine rumen. Front. Microbiol. 8:425.

Van Vuuren, A. M., L. Kruijt, H. C. A. Widjaja, A. Klop, A. J. Cnossen, D. Anjema, and J. van Baal. 2013. Influence of DGAT1 polymorphism on response of dairy cows to ruminal supplementation of linseed oil. Pages 279-281 in Energy and Protein Metabolism and Nutrition in Sustainable Animal Production. J. W. Oltjen, E. Kebreab, and H. Lapierre, ed. Wageningen Academic Publishers, Wageningen, the Netherlands.

van Zijderveld, S. M., J. Dijkstra, H. B. Perdok, J. R. Newbold, and W. J. J. Gerrits. 2011b. Dietary inclusion of diallyl disulfide, yucca powder, calcium fumarate, an extruded linseed product, or medium-chain fatty acids does not affect methane production in lactating dairy cows. J. Dairy Sci. 94:3094-3104.

van Zijderveld, S. M., W. J. J. Gerrits, J. Dijkstra, J. R. Newbold, R. B. A. Hulshof, and H. B. Perdok. 2011a. Persistency of methane mitigation by dietary nitrate supplementation in dairy cows. J. Dairy Sci. 94:4028-4038.

Veneman, J. B., S. Muetzel, K. J. Hart, C. L. Faulkner, J. M. Moorby, H. B. Perdok, and C. J. Newbold. 2015. Does dietary mitigation of enteric methane production affect rumen function and animal productivity in dairy cows? PLoS One 10:e0140282.

Wallace, R. J., J. A. Rooke, C. A. Duthie, J. J. Hyslop, D. W. Ross, N. McKain, S. Motta de Souza, T. J. Snelling, A. Waterhouse, and R. Roehe. 2014. Archaeal abundance in post-mortem ruminal digesta may help predict methane emissions from beef cattle. Sci. Rep. 4:5892.

Wang, M., R. Wang, P. H. Jansen, X. M. Zhang, X. Z. Sun, D. Pacheco, and Z. L. Tan. 2016. Sampling procedure for the measurement of dissolved hydrogen and volatile fatty acids in the rumen of dairy cows. J. Anim. Sci. 94:1159-1169.

Zened, A., S. Combes, L. Cauquil, J. Mariette, C. Klopp, O. Bouchez, A. Troegeler-Maynadier, and F. Enjalbert. 2013. Microbial ecology of the rumen evaluated by 454 GS FLX pyrosequencing is affected by starch and oil supplementation of diets. FEMS Microbiol. Ecol. 83:504-514. 